\title{
Asset-liability models and the Chinese basic pension fund
}

Article

Accepted Version

Zhao, Z. and Sutcliffe, C. (2021) Asset-liability models and the Chinese basic pension fund. Economic and Political Studies, 9 (2). pp. 186-216. ISSN 2095-4816 doi:

https://doi.org/10.1080/20954816.2020.1793497 Available at https://centaur.reading.ac.uk/90414/

It is advisable to refer to the publisher's version if you intend to cite from the work. See Guidance on citing.

To link to this article DOI: http://dx.doi.org/10.1080/20954816.2020.1793497

Publisher: Taylor \& Francis

All outputs in CentAUR are protected by Intellectual Property Rights law, including copyright law. Copyright and IPR is retained by the creators or other copyright holders. Terms and conditions for use of this material are defined in the End User Agreement.

\section{www.reading.ac.uk/centaur}

\section{CentAUR}

Central Archive at the University of Reading

Reading's research outputs online 


\title{
Asset-Liability Models and the Chinese Basic Pension Fund
}

\author{
Zucheng Zhao* and Charles Sutcliffe ${ }^{\$}$ \\ * The ICMA Centre, Henley Business School, University of Reading, PO Box 242, Reading, \\ RG6 6BA, UK, email: Zucheng.Zhao@pgr.reading.ac.uk \\ \$ The ICMA Centre, Henley Business School, University of Reading, PO Box 242, Reading, \\ RG6 6BA, UK, email: c.m.s.sutcliffe@rdg.ac.uk, ORCID 0000-0003-0187-487X
}

4 April 2020

\begin{abstract}
Pillar 1B (individual accounts) of the Chinese basic pension fund (BPF) have suffered from substantial underfunding due to a series of challenges such as rising longevity, conservative investment policies, and the fragmentation of the pension system. Using an asset-liability model (ALM) we investigate the effects of the pre-2015 and post-2015 limits on asset allocations, as well as no limits. We also investigate the likely effect on investment performance of transferring the pillar 1B funds to the Council of National Social Security Fund (NSSF) and raising the retirement age to 65. We find that an ALM is superior to an assets-only analysis, removing the limits on investment in domestic assets (but not foreign assets) would be beneficial, as would transferring the assets to the NSSF, and raising the retirement age. Finally, the official notional rate on individual accounts should be set at a realistic level.
\end{abstract}

Keywords: Pension Scheme; Portfolio Theory; Asset-Liability Model; Retirement Age; Cash Balance

JEL: G11; H55; H75

We wish to thank Erick Fung, Shuyuan Qi, Chengcheng Miao and Jing Ning (University of Reading) for their comments on an earlier draft of this paper.

Highlights - An asset-liability model is preferable to an assets-only model

- Removing the limits on domestic investment would be beneficial

- Removing the limits on foreign investment would not be beneficial

- Transferring assets to the NSSF would improve investment performance

- Later retirement and lower annuity factors would improve the funding ratio 


\section{Asset-Liability Models and the Chinese Basic Pension Fund}

After over 30 years of economic reform China has established a three-pillar pension system for urban employees. This system faces the challenges of rising longevity, an increasing ratio of non-workers to workers, an economic slowdown and considerable under funding. Additional challenges include negative real returns on pension investments and a fragmented pension system. The focus of our research is on the investment of the assets of the first pillar of the basic pension fund (BPF), which is by far the largest of the three pillars. The BPF was designed to be a national state pension scheme, with the assets in the individual accounts invested by the provinces. The provinces make their own local decisions, which loosely follow a common set of national regulations; and the central government remains ultimately responsible for any deficits generated by the provinces. In 2015 there were two changes to the regulations governing the investment of BPF assets by the provinces. The upper and lower limits on the proportions of assets invested in different asset classes were changed, and the provinces were allowed to transfer their BPF assets to the Council of National Social Security Fund (NSSF) to invest on their behalf in a pooled manner, subject to national investment restrictions.

The four main questions on which we focus are: how is the asset allocation and performance of the BPF affected by the inclusion of the BPF liabilities in the portfolio model; what are the effects of the various investment regulations on the BPFs optimal asset allocation and performance; will transferring the funds to the NSSF improve performance, and what would be the effects on the asset allocation, liabilities and investment performance of the BPF of raising the retirement age to 65 ? To answer our first question, we compare the results of a conventional assets-only mean-variance model with that of an asset-liability model (ALM). For our second question we solve the ALM with three different sets of investment restrictions. Our third question investigates the extent to which the NSSF's superior investment performance is due to their different investment restrictions, or to other factors. Finally, we use an ALM to study the effects of raising the retirement age to 65 to answer our last question. We compute the optimal asset allocations in 2016 using annual data for the asset and liability classes from 2001 to 2016. For both active members and pensioners, we disaggregate the liabilities into male employees, female officers in public institutions and female blue-collar workers, making six groups in total. 
This is the first study of the BPF to compare the assets-only efficient frontier to that of an ALM with six groups of pension liabilities, the first to use an ALM to compare the effects of the pre-2015, post-2015 and no investment restrictions on the efficient portfolio of the BPF. We are also the first to use an ALM to analyse the effects of outsourcing the BPF investment of pension funds to the NSSF, and the first to investigate the effects on the efficient frontier of an ALM of raising the retirement age of the BPF to 65.

We find that using an ALM is preferable to an assets-only analysis, and that the pre2015 investment limits were very restrictive. Relaxing the post-2015 limits on domestic assets, but not foreign assets, would allow an improvement in performance; and removing all limits would permit much higher returns, but also lead to much high risk. Investment of pillar 1B funds by the NSSF would probably improve investment performance. Instantaneously raising the retirement age would worsen the funding ratio, but a phased change should improve the funding ratio. The notional rate of return of over $8 \%$ on the investment accounts set recently by the government (MOHRSS, 2017c) will probably worsen the funding ratio as it exceeds likely investment returns.

This paper is structured as follows: Section 1 provides background information on the Chinese pension system, the investment restrictions, the challenges it faces and the various reforms. Section 2 introduces the ALM approach to setting the asset allocation for defined benefit (DB) pension schemes. Section 3 presents our ALM model. Section 4 describes the calculation of the liabilities, and Section 5 reports the asset data we use. Our results follow in Section 6, and Section 7 concludes.

\section{Background}

\subsection{Three-Pillar Pension System in China}

Starting with the economic reforms in the 1980s, a multi-pillar pension fund system was established in urban China (Oksanen, 2012). This system can be divided into three pillars - the BPF (pillar 1), the enterprise annuity (pillar 2) and private annuities (pillar 3) (Dong and Wang, 2016). There are some differences between those who work in the public and private sectors, and between those who live in urban and rural areas. All those who work in for-profit enterprises must participate in the BPF, which is also called Basic Old Age Insurance. Civil servants working in non-profit public institutions must join the Public Employee Pension (PEP), which was merged into the BPF in 2015. By the end of 2016 the BPF had 278.26 million active 
members and 101.03 million pensioners (Ministry of Human Resources and Social Security (MOHRSS), 2017a). The BPF is divided into two parts: pillar 1A operates as a DB scheme on a pay-as-you-go (PAYG) basis, and pillar 1B is designed to be fully funded individual accounts.

Only a few authors have considered whether pillar 1B of the BPF is a DB or defined contribution (DC) scheme. The OECD (2017) describes the individual accounts of pillar 1B as DC. But these accounts are largely notional, with interest credited at a rate set by the government, and benefits received as a lifetime annuity (Bateman and Liu, 2017). The government, in the form of the province, is responsible for investing the money in these accounts, and for any deficits (Dorfman et al., 2013; Wang et al., 2014a). DC schemes are not run in this way. For example, members of American 401(k) schemes are responsible for deciding how to invest their pension pots and may decide how much to contribute. They also decide how and when to receive benefits, and bear all the investment risk (Bassett et al., 1998). The operation of pillar 1B resembles a cash balance scheme, which is somewhere between DB and DC. Because members typically have an individual account and receive benefits as a lump sum at retirement, cash balance schemes look like DC schemes. But they are generally classified as a type of DB scheme, as the sponsor invests the assets and bears the investment risk (Cahill and Soto, 2003). Therefore, in this study, we define pillar 1B as a DB cash balance scheme.

Pillar 1 of the BPF covers urban employees in full-time jobs, or with permanent contracts. In 2009 the New Rural Resident Pension (NRP) was established for non-employed rural residents, and in 2011 the Urban Resident Pension (URP) was created for urban nonemployed residents. Ning et al. (2016) find that the NRP does not improve the wellbeing of the elderly, particularly those in bad health. In 2014 the merger of these two voluntary schemes into the Resident Pension was announced, and by 2017 this scheme had 512.6 million participants (Fang and Feng, 2018). It is not part of the three-pillar system.

In 1991 the pillar 2 employer-sponsored Enterprise Annuities (EA) were introduced for employees of large state-owned enterprises (SOE). As a DC scheme, the EA is increasingly offered by employers, and has the advantage that the sponsor is not responsible for the level of pension benefits. At the end of 2016 the EA had 23.3 million members, which was only 5.8\% of the number of BPF participants (Fang and Feng, 2018).

The third pillar (private annuity insurance) is intended to be complementary to the other two pillars, and most products in pillar 3 are DC schemes, with a few old DB schemes. It has 
been growing rapidly, and according to the annual report of the Chinese insurance market, the private annuity market expanded by $16.9 \%$ each year from 2001 to 2014 (Chinese Insurance Regulation Commission, 2015). But the third pillar is still in its infancy. According to Fang and Feng (2018), most existing private annuity products are treated as wealth management products, and not held for long periods. Therefore, these products are unlikely to provide an income in retirement. To develop the private annuity insurance market, on $1^{\text {st }}$ May 2018 a pilot policy of tax relief was launched in the cities of Shanghai and Soochow, and in Fujian province. Investment gains are tax exempt, and $25 \%$ of the annuity payments are also tax exempt. Table 1 summarises the Chinese three pillar pension system.

Table 1: The Structure of the Three Pillars in China

\begin{tabular}{|l|c|c|c|c|}
\hline \multicolumn{1}{|c|}{ Scheme } & Pillar & $\begin{array}{c}\text { Type of } \\
\text { Scheme }\end{array}$ & Contribution Rate & Mandatory \\
\hline BPF: Social Pool & $1 \mathrm{~A}$ & PAYG & Enterprise: $20 \%$ & YES \\
\hline BPF: Individual Accounts & $1 \mathrm{~B}$ & DB Funded* & Individual: $8 \%$ & YES \\
\hline Enterprise Annuities & 2 & DC Funded & $\begin{array}{c}\text { Enterprise and } \\
\text { Individual } \leq 12 \%\end{array}$ & NO** \\
\hline Private Annuity Insurance & 3 & DB/DC Funded & Individual: N.A. & NO \\
\hline
\end{tabular}

* Pillar 1B should be fully funded, but in practice it operates with notional or empty accounts (Liu and Sun, 2016);

** Only large state-owned enterprises offer enterprise annuities to their employees, and they are voluntary for these employees (Hu et al., 2009; Cai and Cheng, 2014). Other sources: Feldstein (1999), Song (2009), MOHRSS (2017a) and Fang and Feng (2018).

\subsection{Challenges to Pillar 1B}

Over the coming decades most countries will face a higher dependency ratio (nonworkers/workers) due to rising longevity and falling birth rates. This issue will be more severe in China than any other country due to its very large population and one-child policy ${ }^{1}(\mathrm{Li}$ and Mérette, 2005). Peng (2008) forecasts that the demographic shift in China will be rapid, with the proportion of those over 60 years old increasing from 6.9\% in 2000 to $15.7 \%$ in 2030. Leung (2003) estimates that a '4-2-1' dependency ratio will appear in 2030: that is, the caring responsibility for two parents and four grandparents will rely on a solo adult child. This

\footnotetext{
${ }^{1}$ In 2016 the one-child policy was replaced by the two-child policy (Feng et al., 2016).
} 
challenges the financial sustainability of the pillar 1A PAYG system. In 2030 cash outflows from the PAYG pillar 1A are forecast to exceed its cash inflows, and by 2037 the scheme's reserve fund will be exhausted, (Xu et al., 2017). So, on current projections, from 2037 onwards pillar 1A will have insufficient funds to meet its obligations. Since the provinces are responsible for paying the pillar 1A pensions, funding problems will emerge earlier in provinces with a recession.

The individual accounts in pillar 1B have suffered from the fragmentation of the BPF across the provinces, and their excessively conservative investment policies. Pillar 1B funds are pooled at the provincial level, or even at the county level; and each local government has considerable autonomy in operating the BPF and investing its assets (Frazier, 2010; Barr and Diamond, 2010). Some local governments in poor areas, or those with a recession, have used the accumulated assets in pillar 1B to finance their current payments to pillar 1A pensioners (Sin, 2005; Liu and Sun 2016). Therefore, the individual accounts in some provinces are notional, with no assets in the individual accounts (empty accounts). There are also significant differences in the pension payments and conditions of pensioners of the urban, rural, SOE, public institution and civil service schemes, leading to unfairness (Lin, 2004; Wang et al, 2014b; Jia, 2017).

\subsection{Reforms of Pillar 1B}

The literature has discussed possible reforms to pillar 1B to ease the challenges it faces, such as raising the retirement age, pooling investment of the assets, and more flexible investment constraints.

\subsubsection{Delaying Retirement}

Raising the retirement age is a direct remedy for pension underfunding, and has been used by pension schemes in many other countries. A higher retirement age means there will be more contributors and fewer pensioners. In China the mandatory retirement age is currently low at 60 years for male workers, 55 years for female officers in public institutions, and 50 years for female blue-collar workers (Liu et al., 2015). In practice, the average male retirement age is 56 years, and that of females is around 50 years (James, 2002). Simulation results indicate that raising these retirement ages to 65 can postpone the time when the cash flow of the pillar $1 \mathrm{~A}$ PAYG system becomes negative by 15 years (Wang et al., 2004).

However, these simulations implicitly assume that, if their retirement age is raised, members will continue to be employed. Fang and Zhang (2018) recently challenged this 
assumption. They show that the growth rate of the productivity of Chinese workers is much higher than that in developed countries. In the manufacturing and textile industries there is a surfeit of workers, and so the Chinese economy does not need to employ elderly workers to increase output. Moreover, for full-time workers in China there is a strong positive correlation between age, or years of service, and salary. Therefore, organisations may be reluctant to hire elderly workers on higher salaries. In consequence, an increase in the retirement age might not be successful, as older workers may be unable to find employment.

\subsubsection{More Lenient Investment Restrictions}

To provide 'absolute safety' to pensioners, until 2015 investment by the pillar 1B scheme was restricted to bank deposits, domestic treasury bills and Chinese government bonds (Hu et al., 2007). These assets were too conservative to beat inflation, and the provincial pillar 1B funds experienced average negative real returns from 2011 to 2015. During this period the average nominal return on pillar $1 \mathrm{~B}$ assets was $2.5 \%$, while the average inflation rate was $2.7 \%$ (Dong and Wang, 2016; Zhang and Harte, 2017).

Table 2: Chinese Investment Restrictions on Pillar $1 B$ Funds and the Social Security Fund ${ }^{2}$

\section{Provincial investment of pillar 1B funds, pre-2015}

At least $20 \%$ in domestic fixed income and money market instruments with a maturity of under one year.

At least $20 \%$ in government bonds with a maturity of at least one year.

\section{Provincial and NSSF investment of pillar 1B funds, post-2015}

At least 5\% in domestic fixed income and money market instruments with a maturity of under one year.

Not more than $30 \%$ in domestic equity

\section{NSSF investment of the Social Security Fund, 2006 onwards}

At least 50\% in domestic and foreign bank deposits and government bonds

Not more than $10 \%$ in domestic and foreign corporate bonds

Not more than $40 \%$ in domestic and foreign equity

Not more than $20 \%$ in total foreign investments

\footnotetext{
2 The Social Security Fund was established in 2000, and the Chinese government described it as a 'strategic reserve fund' and 'the last ditch to the problem of ageing'. The assets of the Social Security Fund come from four sources: allocations from the central government's treasury, equities of SOEs, state lottery proceeds and its own investment revenues (Leckie and Pan, 2007). The Social Security Fund was the only fund managed by the NSSF before pooled investment of the BPF pillar 1B funds was permitted in 2015.
} 
Note: No investment is permitted in any asset not mentioned in the regulations. Sources: Hu et al. (2007), Leckie and Pan (2007) and The State Council (2015).

With the introduction of new investment regulations for the pillar 1B individual accounts in 2015, the investment restrictions started to be eased. According to the new constraints, in contrast with the pre-2015 limits, the minimum investment in short-term investment vehicles (the duration of the investment is less than one year) decreased from $20 \%$ to $5 \%$. The minimum proportion of $20 \%$ of assets under management (AUM) in one-year plus fixed income investments was removed; and the asset classes in this section were no longer limited to government bonds and term deposits (Hu et al., 2007). An allocation of the pillar 1B assets to equities was allowed for the first time, with a maximum proportion of $30 \%$, but only in domestic equities (State Council, 2015). Not only is investment by pension funds in domestic equities likely to improve the investment performance of pension portfolios, but it will also help stabilise and expand the Chinese equity market and improve market efficiency (see Faugere and Shawky, 2003; Bohl et al., 2009; Alda, 2017). The investment restrictions (including those of the Social Security Fund) are summarised in Table 2.

\subsubsection{Pooled Investment of the BPF Assets}

The fragmented nature of the BPF has resulted in a series of problems, e.g. restricted labour mobility, and higher administration and investment costs. When migrant workers switch jobs from rural to urban areas, or from one province to another, they have to give up a proportion of the accumulated contributions in their individual accounts to transfer their pensions to the new scheme (Yang and Zhou, 2017). In some cases, they may have to give up all the accumulated benefits in their pillar 1B pensions (Zuo, 2014). This is because, when a migrant worker switches his/her job from one province to another, only the actual money (often less than the notional value of the individual account) is transferred, due to the problem of empty accounts. This discourages labour mobility in China.

In 2015 the State Council of China issued the 'Regulations on the Basic Pension Fund Investment Management'. From December 2016 these regulations permit provinces to transfer their BPF pillar 1B assets to the NSSF to invest in a pooled manner, subject to the pillar 1B investment regulations. By the end of 2017 nine provinces had transferred about 430 billion Chinese yuan (accounting for 12\% of the total assets in pillar 1B) to the NSSF (NSSF, 2018). The central government is currently encouraging the other provinces to outsource the investment of their pillar 1B pension funds to the NSSF. 
The NSSF, which is not part of any pillar of the pension system, has a better historical investment performance than the BPF (NSSF, 2018). The NSSF has managed the Chinese Social Security Fund since 2000, achieving an average annual return of $8.37 \%$. The returns of the NSSF are higher than almost all the wealth management products in China, and higher than the weighted average return of the EAs $(7.57 \%)$ over the same period (Hu, 2017). The NSSF uses both internal and external fund managers, and Shen et al. (2019) show that from 2000 to 2016 the external fund managers of the Social Security Fund earned better risk-adjusted returns than the internal managers, with five generating positive alphas; while funds managed internally by the NSSF failed to achieve a positive alpha. Shen et al. (2019) find that private information and alumni networks at fund management companies contributed to the total investment performance of the Social Security Fund, even though insider trading is not allowed in China. Although the Social Security Fund is subject to different investment restrictions to the BPF, these results suggest that pooled management by the NSSF of the pillar 1B funds has the potential to bring better investment performance. Pooled management of pension portfolios by the NSSF will also reduce the growth of the problem of notional individual accounts, as provinces will find it hard to remove money from the NSSF, except for the purpose of paying 1B pensions. This should improve labour mobility, as individual accounts will be less empty.

The fragmentation of the BPF into many small pension pools has led to higher overall investment costs. Large pension funds can benefit from economies of scale, such as lower administration expenses, the attraction of in-house experts and access to additional types of asset, e.g. direct property, infrastructure, hedge funds and private equity. Evidence of this can be found in the large Canadian and US DB schemes that access asset classes unavailable to smaller schemes (Mitchell and Andrews, 1981; Chemla, 2004; Bikker, 2017). In-house expertise can bring further cost reductions and boost returns for large pension funds (Dyck and Pomorski, 2011). Pooled investment of the BPF assets by the NSSF offers the advantages of much more professional management ${ }^{3}$, lower investment costs due to economies of scale, and greater exposure to equities.

\section{Asset-Liability Models of DB Pension Schemes}

DB schemes have different objectives from other institutional investors. The goal of DB schemes is to accumulate enough assets to meet their liabilities, not to maximise their returns;

\footnotetext{
${ }^{3}$ Only a few coastal provincial administrative regions, such as Shanghai City and Shandong Province, have experience of selecting and hiring external asset managers.
} 
and so asset performance relative to the liabilities is more important than beating a benchmark (Sutcliffe, 2016). A scheme has a fully hedged position if it can make its pension benefit payments, no matter how the values of its assets and liabilities fluctuate. The asset allocation decision of DB schemes can be treated as a portfolio problem, where the aim is to invest the funds to minimise the combined asset and liability risk, subject to a given rate of return. This can be addressed by expanding the traditional Markowitz portfolio model to include the liabilities, creating a single period ALM (Sharpe and Tint, 1990; Ezra, 1991; Craft, 2001 and 2005).

Board and Sutcliffe (2007) used annual data from 1981 to 2002 in an ALM to optimise the asset allocation of the Universities Superannuation Scheme (USS), which is the largest UK DB pension scheme. They found that inclusion of the liabilities altered the efficient frontier. The assets-only efficient frontier lay to the north east of the ALM efficient frontier, with different portfolio weights for any given level of risk or return. This shows that including the liabilities affects the optimal portfolio weights, and managers of DB pension funds should not ignore the liabilities when investing the funds. Using assets-only and ALM portfolio models, Hoevenaars et al. (2008) explored the intertemporal covariance structure of US assets and liabilities. They conclude that an assets-only model tends to select short-term assets (e.g. Tbills) because of their low risk in the short run, and good diversification with stocks in the long run. But when liabilities are added to the model, long-term investment assets tend to be selected, as they provide a better hedge against duration mismatch risk with respect to the liabilities.

In the only previous study of the asset allocation of pillar 1B, Jin (2017) used an ALM to compute the optimal asset allocations from 2009 to 2014 . He concluded that pillar 1B has a low funding ratio (below 70\%), and to remove this underfunding without central government subsidies, more assets need to be allocated to equity markets, or the government contribution rate should be raised. However, his model does not include the investment restrictions on pillar 1B investments which have an important effect on the asset allocation. The retirement age, annuity factor, salaries, average age at the valuation, and life expectancy differ as between active members and pensioners, males and females, and job types; but Jin's model does not disaggregate the liabilities.

\section{Methodology}

\subsection{Calculation of the Actuarial Liability}


Calculation of the actuarial liability is the first step in constructing an ALM model of Chinese individual accounts (pillar 1B). Board and Sutcliffe (2007) divided the liabilities into three parts: active members, deferred pensioners and pensioners. Because the retirement age is based on gender and occupation in China, we divide the individual account liabilities of pillar 1B into three groups: male members (retirement at 60), female officers in public institutions (retirement at 55) and female blue-collar workers (retirement at 50). We further divide the calculation of the actuarial liability for each group into two sections: active members and pensioners ${ }^{4}$. As membership of pillar 1B is mandatory for urban employees, it has no deferred pensioners.

We use extended versions of the formulae for actuarial liabilities provided by the Actuarial Education Company (2002), adapted for a cash balance scheme. Our actuarial model for active members is:

$$
\begin{aligned}
A L_{a i}=N_{a i} \times\left(\frac{P o t_{P i}}{A F_{i}}\right) \times\left\{\frac{\left(1+g_{i}\right)}{(1+h)}\right\}^{R_{i}-G_{i}} \\
\times\left\{\frac{\left[1-\left(\frac{1+h}{1+p}\right)^{-W_{i}}\right]}{\left(\frac{1+h}{1+p}-1\right)}\right\}
\end{aligned}
$$

where:

$i=1$ represents male employees, $i=2$ stands for female officers in public institutions and $i=3$ is for female blue-collar workers

$A L_{a i}$ represents the actuarial liability for the active members in each group,

$N_{a i}$ is the number of active members in each group,

$P_{i}$ is the average length of service of each member at the valuation date for each group, $A F_{i}$ is the annuity factor for each group,

$g_{i}$ is the annual forecast nominal salary growth rate for each group between now and retirement,

$h$ is the nominal discount rate between now and retirement,

$\operatorname{Pot}_{P i}$ is accumulated notional value of a member's individual account at the valuation date for each group,

$R_{i}$ is the statutory retirement age in China for each group,

$G_{i}$ is the average age of members in each group at the valuation date,

\footnotetext{
${ }^{4} \mathrm{We}$ aggregate the liabilities in these six groups across all the provinces. Since the proportions of these six liabilities and their age distributions differ as between provinces, our ALM solutions apply to China as a whole, and may differ at the provincial level.
} 
$W_{i}$ is the life expectancy of members in each group at retirement, and $p$ is the growth rate of the price level.

The term $P o t_{P i}$ can be expressed as:

$$
\begin{gathered}
\operatorname{Pot}_{P i}=C\left[S_{i, m}+S_{i, m-1}\left(1+N R_{i, m}\right)+S_{i, m-2}\left(1+N R_{i, m}\right)\left(1+N R_{i, m-1}\right)+\cdots+\right. \\
\left.S_{i, 1}\left(1+N R_{i, m}\right)\left(1+N R_{i, m-1}\right) \ldots\left(1+N R_{i, 2}\right)\right]
\end{gathered}
$$

where:

$C$ is a constant contribution rate, which equals to $8 \%$ according to Table 1 ,

$S_{i, m}$ is average member's annual salary for each group in period $\mathrm{m}\left(1 \leq \mathrm{m} \leq P_{i}\right)$, and $N R_{i, m}$ is the notional rate of return for each group in period $\mathrm{m}$.

Our model of the actuarial liability for pensioners is:

$$
A L_{p i}=N_{p i} \times P E N_{i} \times\left\{\frac{\left[1-\left(\frac{1+h}{1+p}\right)^{-W A_{i}}\right]}{\left(\frac{1+h}{1+p}-1\right)}\right\}
$$

where: $A L_{p i}$ is the actuarial liability for the pensioners in each group,

$N_{p i}$ represents the current number of pensioners in each group,

$W A_{i}$ is the life expectancy of pensioners at the valuation date, and

$P E N_{i}$ are the average annual current pension for each group at the valuation date.

Therefore, the total actuarial liability $\left(A L_{T}\right)$ of the scheme is the sum of the liabilities for these six groups:

$$
A L_{T}=\sum_{i=1}^{n=3}\left(A L_{a i}+A L_{p i}\right)
$$

\subsection{Forecasting Salaries}

The Chinese economy has made rapid progress since its reform in 1978, and GDP experienced double-digit growth until 2010. The annual average salary growth rate for Chinese urban employees from 2002 to 2016 was similar to the growth in GDP, with an average annual growth rate of 12.32\% (MOHRSS, 2017a). However, it would be unreasonable to adopt this historic growth rate as a forecast of the future growth rate, as it is unlikely that the Chinese economy will keep expanding at such a high rate over the next 25-30 years. To estimate a more realistic 
salary growth rate, we use a logistic growth model with an upper bound to forecast annual salaries, which is a modified version of Fan (2010).

$$
y_{t}=\frac{K}{1+\alpha e^{-\beta \Delta t}}
$$

where: $y_{t}$ is the average annual salary in year $\mathrm{t}$,

$K$ is the upper bound on average annual salary,

$\alpha$ is a coefficient,

$\beta$ is the annual salary growth rate in the previous year,

$\Delta t$ is the number of years since 1990 , and

$e$ is the mathematical constant

Equation (4a) can be rewritten as:

$$
\ln \left(\frac{K}{y_{t}}-1\right)=\ln (\alpha)-\beta \Delta t
$$

The strategic objective of China's economic development is to become a medium-level developed country by the mid- $21^{\text {st }}$ century. Therefore, following Wei and Qiu (2014), we assume the ceiling on average annual salary $(K)$ is 305,875 CNY (US\$50,000). They applied linear regression to equation (4b), using the average annual salaries of urban employees in Sichuan province from 1991 to 2012. Their estimates of the coefficients in equation (4b) can be transformed back into equation (4a):

$$
y=\frac{305875}{1+154.3774 e^{-0.1444 \Delta t}}
$$

where $\alpha$ is significant at $10 \%$ level, and $\beta=0.1444$ is significant at the $5 \%$ level.

We use equation (4c) to forecast salaries. The forecast salary growth rate per annum $\left(g_{i}\right)$ is the average logarithmic return on the forecast annual salaries between the valuation date and retirement. Since the three liability groups in China entered employment at different average ages and have different statutory retirement ages, the average salary growth rates for each group are different.

\subsection{Asset-Liability Model}


DB schemes must meet their obligations to present and future pensioners in full, and so the liabilities are included in the extended version of the traditional portfolio model. Assuming that the value of the actuarial liabilities is unaffected by the fund's asset allocation (Inkmann et al., 2017), the ALM can be stated in mean-variance terms with the addition of the covariances between the liabilities and asset classes, and the rates of change in the value of the liabilities.

We expand the Sharpe and Tint (1990) model by dividing the total liability into six groups, which have different correlations with the various asset classes. We identify three groups (male employees, female officers in public institutions and female blue-collar workers) and two types of members (active members and pensioners).

The extended portfolio model with six types of liability is:

$$
\begin{gathered}
\text { Minimise } V_{A L}=\sum_{j=1}^{N+B} \sum_{k=1}^{N+B} x_{j} x_{k} \operatorname{COV}_{j k} \\
\text { Subject to: } R_{A L}=\sum_{j=1}^{N} x_{j} R_{j} \\
\sum_{j=1}^{N} x_{j}=1 \\
x_{j} \geq 0, \quad j=1,2,3, \ldots, N \\
x_{k}=\frac{-A L_{a i}}{A_{0}} \text { or } \frac{-A L_{p i}}{A_{0}}, \quad k=a i, p i
\end{gathered}
$$

plus any additional constraints on the asset weights $\left(x_{j}\right)$, where:

$V_{A L}$ is the variance of the asset-liability portfolio,

$j$ and $k$ represent asset and liability classes,

$N$ and $B$ are, respectively, the number of assets and liabilities,

$C O V_{j k}$ are the covariances of returns on asset or liability classes $j$ and $k$,

$R_{A L}$ is the expected return of the asset-liability portfolio,

$R_{j}$ is the expected return on each asset class,

$x_{j}$ is the portfolio weight of each asset class, 
$x_{k}$ is the initial ratio of each type of actuarial liability to the initial value of the assets, it has a negative sign and is fixed,

$A_{0}$ is the current value of the fund's assets,

$A L_{a i}$ represents the actuarial liability for the active members in each group, and

$A L_{p i}$ is the actuarial liability for the pensioners in each group.

By repeatedly solving this quadratic problem for a range of portfolio returns $\left(R_{A L}\right)$, an asset-liability efficient frontier can be computed for comparison with the conventional assetsonly efficient frontier. This is computed in a similar way to the ALM frontier, but with the liability terms removed from the model. According to the BPF investment regulations, short selling is prohibited to avoid the risks involved, and this has an important effect on the optimal asset allocation (Sutcliffe, 2005). Because the liability weights are fixed, changes in the value of the liabilities and covariances between the various types of liability have no implication for the asset weights of the efficient frontier, and can be set to zero.

\subsection{Hedging Effectiveness}

After computing the asset-liability efficient frontier, we use Ederington's (1979) statistic to measure the hedging effectiveness of the portfolios. This is the reduction in the variance of the asset-liability portfolio, relative to the variance of the liabilities, and can be expressed as follows:

$$
H E=1-\frac{V_{A L}}{V_{L}}
$$

where: $H E$ is the hedging effectiveness,

$V_{A L}$ denotes the variance of the asset-liability portfolio, and

$V_{L}$ represents the variance of the fund's actuarial liabilities.

\section{Estimating the Liabilities}

To estimate the actuarial liabilities for each group of active members and pensioners for 20012016, we use data from the China Labour Statistical Yearbooks ${ }^{5}$. For example, the number of active members and pensioners, the average pension benefits and so on were collected from

\footnotetext{
${ }^{5} \mathrm{We}$ assume the pension contributions in year $\mathrm{t}$ in the individual accounts will be increased by at the notional rates of return in year $t+1$.
} 
these yearbooks. The average age of each group at the valuation date was estimated using the educational attainment of urban employees in these yearbooks. For those with no senior school qualifications we assume an entry age of 16 , which is the minimum legal working age in China. For senior school and medium vocational education graduates we assume an entry age of 18; and for those with a high-level vocational education and college graduates we assume an entry age of 21. For bachelor's degree holders we assume 22, and for master's and $\mathrm{PhD}$ degree holders we assume 25. We find that the average entry age gradually increased between 2001 and 2016 for both genders, reflecting the increasing academic qualifications of employees. In 2015 the average entry age of female employees overtook that of male employees. This may be because Chinese companies tend to prefer men when they hire skilled workers and noncustomer-oriented managers; and to overcome this preference women need higher academic qualifications (Kuhn and Shen, 2012).

Life expectancy at retirement for male and female employees from 2001 to 2016 was collected from the World Bank's (2018) database. The database of the National Bureau of Statistics of China (2018) provides the average annual salary of urban employees, and the annual consumer price index for calculating the inflation rate. In urban China the salary gap between male and female employees has been rising since the 1980s. The China Urban Labour Survey (CULS) of 2001 found that the average hourly earnings of females were almost $20 \%$ lower than for males, and $84 \%$ of this difference cannot be explained by differences in individual endowments. This large difference can be viewed as evidence of gender discrimination against females, although other unknown factors may also contribute to this gap (Wang and Cai, 2008). We follow the CULS survey and assume that the average annual salary of women is around $16 \%$ lower than that for men. We estimate the average annual salaries of males and females in each of the three groups using the proportions of male and female employees in each group.

Chinese monthly pension payments are computed by dividing the final value of a member's accumulated pension pot by an annuity factor, as in equation 1 . Because the retirement age and average life expectancy are different for each group, the annuity factors are also different. It is 139 for male workers, 170 for female officers in public institutions and 195 for female blue-collar workers (MOHRSS, 1997; Li and Lin, 2019). For each liability estimation, the discount rate is the current 10-year Chinese government bond yield in each year. Summary statistics of the demographic data used to calculate the actuarial liabilities of the six groups are displayed in Appendix 1. 
The computation of the six liabilities each year allows for changes in the number of active members and pensioners in each group, the level of inflation, the average salary and other demographic factors (e.g. life expectancy), and changes in the notional rate of return. According to the regulations ${ }^{6}$, to diminish the unfairness of the fragmented pillar 1B system, every province must update the balance of individual accounts each year by at least the 1-year commercial bank deposit rate (MOHRSS, 2017b). However, this rate is lower than the inflation rate for some periods. Before the launch of this regulation, each provincial or city-level authority could set their own notional rate of return. We use the 10-year Chinese government bond yield as the notional rate of return for each liability estimate, except for 2014-2016. Based on the policy notice of MOHRSS (2017c), the notional rate of return on individual accounts (pillar 1B) of urban employees is uniformly set at 5\% for $2014-2015$ and $8.31 \%$ for 2016 .

The total actuarial liability has exceeded the total accumulated assets in pillar 1B since 2001, and when required, government subsidies have enabled the provinces to meet their obligation to pay pensions. The deficit has grown to 1,405,645 million Chinese yuan (around US $\$ 200$ billion) in 2016 and, in contrast to Jin (2017), this fiscal burden for the government is forecast to increase further in the future. The accelerating growth of the pillar 1B deficit is consistent with the rapid ageing of the Chinese population, which challenges not only the notional individual accounts, but also the sustainability of the pillar 1A PAYG system (Peng, 2008).

The actuarial liabilities of male employees are larger than for females because there are more male employees. The total actuarial liability of female active officers in public institutions is smaller than for active female blue-collar workers; but their average growth rate is much higher. At the end of 2016 the actuarial liabilities of the three groups of active members, as a proportion of the total scheme assets, were: males $x_{a 1}=-51.04 \%$, female officers in public institutions $x_{a 2}=-12.24 \%$, and female blue collar workers $x_{a 3}=-19.26 \%$. For pensioners they were: males $x_{p 1}=-26.10 \%$, female officers in public institutions $x_{p 2}=-8.66 \%$ and female blue collar workers $x_{p 3}=-19.14 \%$. The total actuarial liability was around 1.36 times the assets, i.e. a funding ratio of $73.50 \%$. The time series of the estimated liabilities for the six liability groups in pillar 1B, together with the total values of the assets and liabilities, are plotted in Figure 1.

${ }^{6}$ http://www.mohrss.gov.cn/SYrlzyhshbzb/zwgk/szrs/tongjinianjian/ , last viewed on 20 January 2019. 


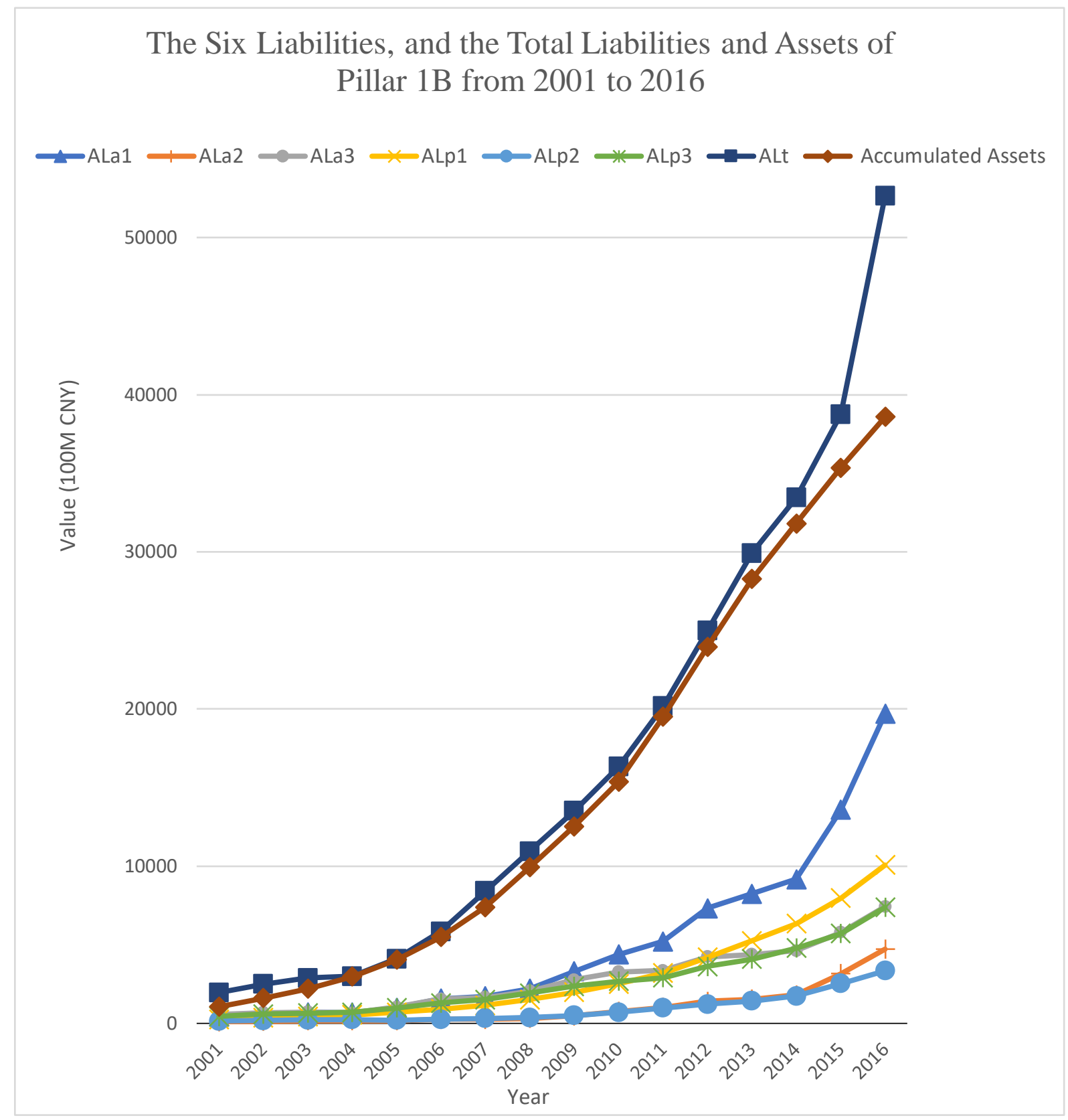

Figure 1: Liabilities and Total Assets

\section{Asset Data}

In compliance with the BPF investment regulations, we include the following assets: the MSCI China A-Level Onshore ${ }^{7}$ Growth total returns index in $\mathrm{CNY}^{8}$, the MSCI China A-Level

\footnotetext{
7 Measures for Unifying and Standardising the Notional Rate of Return on the Individual Accounts of Urban Employees' BPF.

${ }^{8}$ MSCI China A Onshore index captures 537 large and mid-cap constituents of Chinese equities listed on the Shanghai and Shenzhen Exchanges (MSCI, 2019a).
} 
Onshore Value total returns index in $\mathrm{CNY}^{9}$, yields on 10-year China government bonds, the 3month China interbank offered rate provided by DataStream, and yields on the China Corporate Bond Index from S\&P, with yields on the China Corporate Bond (AAA) Index from China Bond $^{10}$ as a supplement due to the shorter time span of yields from the S\&P. The MSCI World index in $\mathrm{CNY}^{11}$, yields on FTSE World Government Bond index - Developed Markets in $\mathrm{CNY}^{12}$ and yields on the FTSE WorldBIG Corporate bond index in $\mathrm{CNY}^{13}$ are used to test the effects of relaxing the restriction on overseas investment. We used annual data from 2001 to 2016 for all the asset classes.

We estimate the actuarial liability for each group and the total actuarial liability using the actuarial models in equations 1-3. We also estimate the rates of change, standard deviations and correlations for the six types of actuarial liability, the expected returns, standard deviations and correlations for each asset class, and the correlations between the asset classes and liabilities (see Table 3). All the expected returns and correlations are tax-exempt, and in Chinese yuan.

\section{Model Results}

We investigate the effects on the investment performance and asset allocation of pillar 1B for four situations - including liabilities in the portfolio model, changing the investment restrictions, outsourcing investment to the NSSF and increasing the retirement age.

\subsection{Including Liabilities in the Model}

For the assets-only model we compute the efficient frontier using five assets (MSCI China Alevel onshore growth index, MSCI China A-level onshore value index, China corporate bond index, 10-year government bond, and the China 3-month interbank deposit rate). Table 4 contains 12 efficient asset allocations when the post-2015 regulatory constraints of the BPF apply, together with their expected return and risk. The BPF 2017 annual report gives a broad indication of its opening asset allocations, $5.5 \%$ of the assets under management (AUM) were

\footnotetext{
9 The growth index captures equities in MSCI China A-Level Onshore Index which exhibit growth style characteristics (MSCI, 2019b).

${ }^{10}$ The value index captures the equities in MSCI China A-Level Onshore Index which exhibit value style characteristics (MSCI, 2019c).

11 The yield curve of the China Corporate Bond (AAA) Index from China Bond:

https://www.chinabond.com.cn/cb/eng/zzsj/cywj/syqx/sjxz/zzqyzqx/list.shtml, last viewed on 31 July 2018

12 The MSCI World Index contains 1,632 large and mid-cap constituents across 23 developed markets countries. It covers around $85 \%$ of the market capitalisation in each country (MSCI, 2019d).

${ }^{13}$ The FTSE World Government Bond Index - Developed Markets measures the performance of fixed-rate, local currency, investment-grade sovereign bonds issued in developed markets (FTSE Russell, 2018).
} 
invested in short-term vehicles, $16 \%$ in long-term government bonds, $48.5 \%$ in corporate bonds, and $30 \%$ in stocks (NSSF, 2018), which complies with the regulatory constraints. The expected returns and standard deviations of returns for the actual BPF portfolio computed using our data appear in Table 4.

In addition to the five asset classes, the ALM with post-2015 restrictions also includes the six fixed liabilities, and Table 4 shows the asset weights and performance of 12 efficient portfolios. 1returns do not include expected liability returns as the liabilities are exogenous. Including the expected liability returns in Figure 2 would shift the ALM frontier downwards by $20 \%$, making it difficult to compare the ALM and assets-only frontiers. Therefore, the figures considerably overstate the expected returns on the combined portfolio of assets and liabilities. This may mislead fund managers and the government into thinking that the current investment regulations are compatible with boosting the sluggish performance of the past ${ }^{14}$.

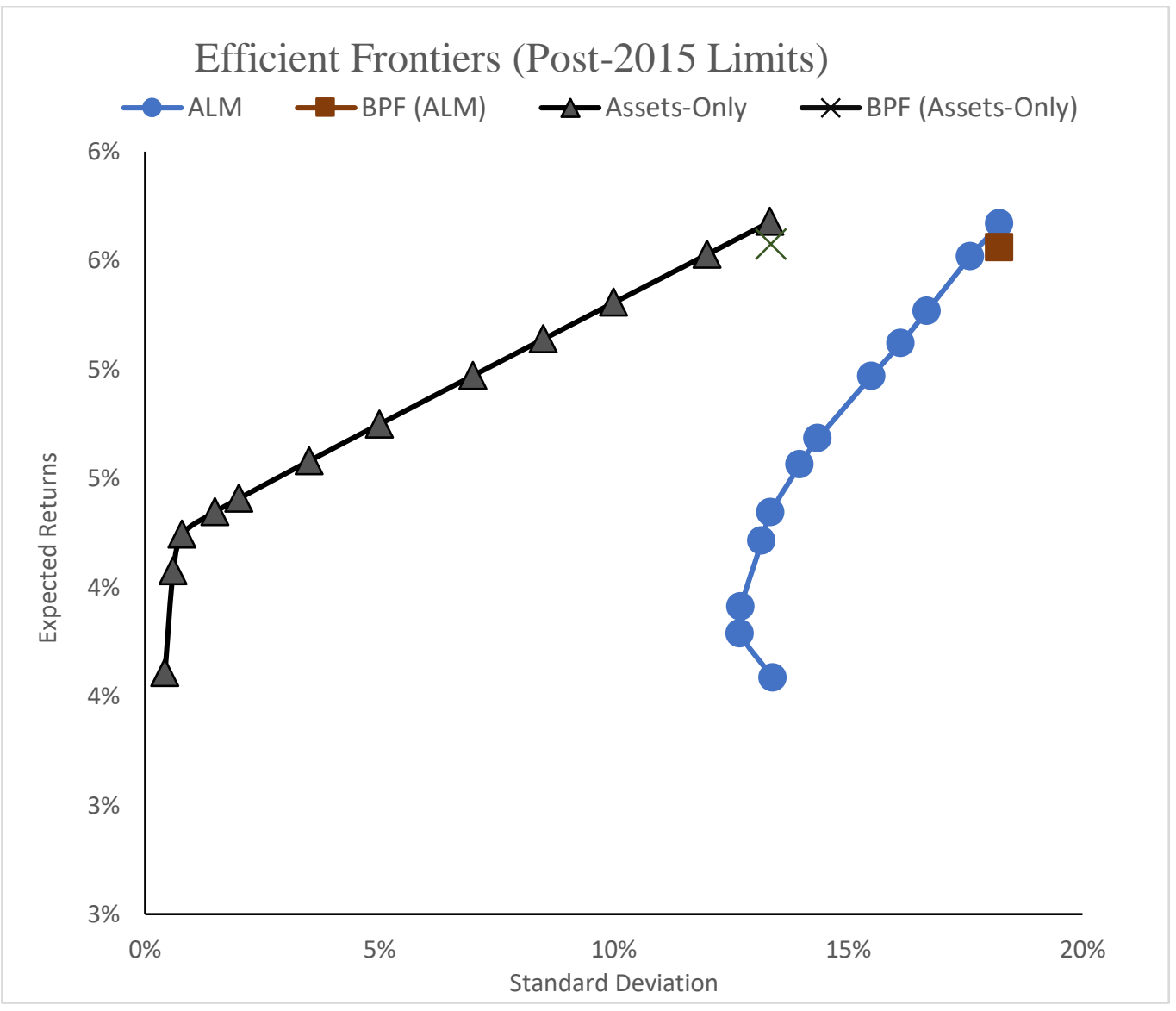

Figure 2: Assets-Only and Asset-Liability Efficient Frontiers

\footnotetext{
${ }^{14}$ FTSE WorldBIG Corporate Bond index is one of the sub-indices of FTSE World Broad Investment-Grade Bond Index, which is a multi-asset, multi-currency benchmark that provides a broad-based measure of the global fixed income market (FTSE Russell, 2019).
} 
The assets-only and ALM efficient frontiers, together with the actual asset allocation of pillar 1B of the BPF, are plotted in Figure 2. This shows that the ALM frontier is not simply a linear transformation of the assets-only frontier. Due to the inclusion of the six types of liability, the shape of the ALM frontier is different, and has substantially higher risk for every level of return. The big increase in risk which shifts the ALM frontier to the right in Figure 2 is due to the incorporation of liability risk in the ALM but not the assets-only frontier. The hedging effectiveness of the ALM is included in Table 4 and shows that portfolio 2 with the funds invested in $82.7 \%$ of 10 -year government bond and $17.3 \%$ of the China Interbank $3 \mathrm{M}$ rate offers the best hedge by reducing the liability risk by $0.94 \%$. For portfolios 4 to 12 , and the actual BPF portfolio, the negative hedging effectiveness means these portfolios are riskier than just the liabilities. For the assets-only model, portfolio 1 is the risk minimising portfolio, with $94.7 \%$ of the funds in 10-year government bonds. Despite their different plots in Figure 2 , the asset weights for the five asset classes exhibit only small differences between the two models. The BPF portfolio plots just below the top end of both the assets-only and ALM efficient frontiers. This shows that the BPF's asset allocation is more or less on the efficient frontier, with almost the highest available expected returns and risk.

\subsection{ALM with Different Investment Restrictions}

Table 2 summarises the various sets of investment restrictions pre- and post-2015 for pillar 1B and the Social Security Fund. In Section 6.1 we computed the ALM efficiency frontier for the post-2015 regulations, and we now compute the efficient frontiers for the pre-2015 pillar 1B regulations, and with no investment restrictions. These plots appear in Figure 3. The differences between these plots reveal the implied cost of these regulations, in terms of their effect on the risk and return of efficient portfolios.

\subsubsection{ALM With Pre-2015 Pillar 1B Investment Restrictions}

The pre-2015 pillar 1B investment limits were very conservative, which caused the negative real return on its investments from 2011-2015, contributing to the problem of empty individual accounts. In this subsection, we compute the ALM efficient frontier under the pre-2015 constraints to see the cost, in terms of risk and return, of pursuing 'absolute safety' with investment in only government bonds and interbank deposits exposures. The efficient portfolios and related hedging effectiveness are included in Table 5.

It can be seen that all 12 portfolios have positive effectiveness, and portfolio 12 provides the largest reduction of $1.70 \%$; but the expected returns for portfolios 2 to 12 are lower 
than for the post-2015 portfolios. While the asset allocation varies, the expected returns and risk of the 12 portfolios with pre-2015 limits are very similar to each other, effectively a single point, which is because the two available assets have similar characteristics. The pre-2015 investment regulations ruled out almost all of the efficient frontier made available by the introduction of the post-2015 limits. The post-2015 BPF asset allocation in Figure 3 shows that once these very restrictive rules were loosened, the BPF moved to a higher risk and return portfolio by transferring $78.5 \%$ of its assets into the newly permitted asset classes. This helped to alleviate the problem of empty individual accounts due to higher investment returns. The benefits from relaxing the investment restrictions in 2015 suggests there may be further benefits from additional relaxation.

\subsubsection{ALM with No Investment Restrictions}

Two previous studies of Chinese pensions have found that allowing investment in foreign assets worsens the Sharpe ratio. In the assets-only investment liberalisation analysis of $\mathrm{Hu}$ et al. (2007), the four hypothetical and arbitrary pension portfolios which allowed investment in foreign assets achieved lower Sharpe ratios than a portfolio with no foreign investment that complied with the pre-2015 investment limits. Pfau (2011) used an assets-only portfolio model with a risk aversion parameter of five to compute efficient portfolios. He found that adding foreign assets to a portfolio of domestic equities and bank deposits led to $99.78 \%$ of the funds being invested in foreign assets. This increased Chinese returns by $60 \%$, but also increased their standard deviation by $66 \%$, which implies a small reduction in the Sharpe ratio.

We now apply the ALM with no investment limits (except for banning short sales), together with eight asset classes, and the results appear in Figure 3 and Table 5. The three additional assets we include are the MSCI World index, the FTSE World Government Bond Developed Markets index and the FTSE WorldBIG Corporate Bond index. Figure 3 shows that the post-2015 investment constraints on pillar 1B investment remove a large part of the efficient frontier. Portfolios 1 and 2 provide positive liability risk hedging, with $1.21 \%$ and $5.78 \%$ reductions, respectively. Portfolios 3 to 12 with no limits only invest in domestic value stocks and domestic corporate bonds. This shows that the ban on foreign equities and fixedincome products in the post-2015 investment limits is not a binding constraint, and its relaxation would provide no benefit. If the BPF wishes to deal with its substantial underfunding, the removal of investment limits on domestic equities and domestic corporate bonds would enable the BPF to achieve a much higher expected return, although this is accompanied by additional risk. 


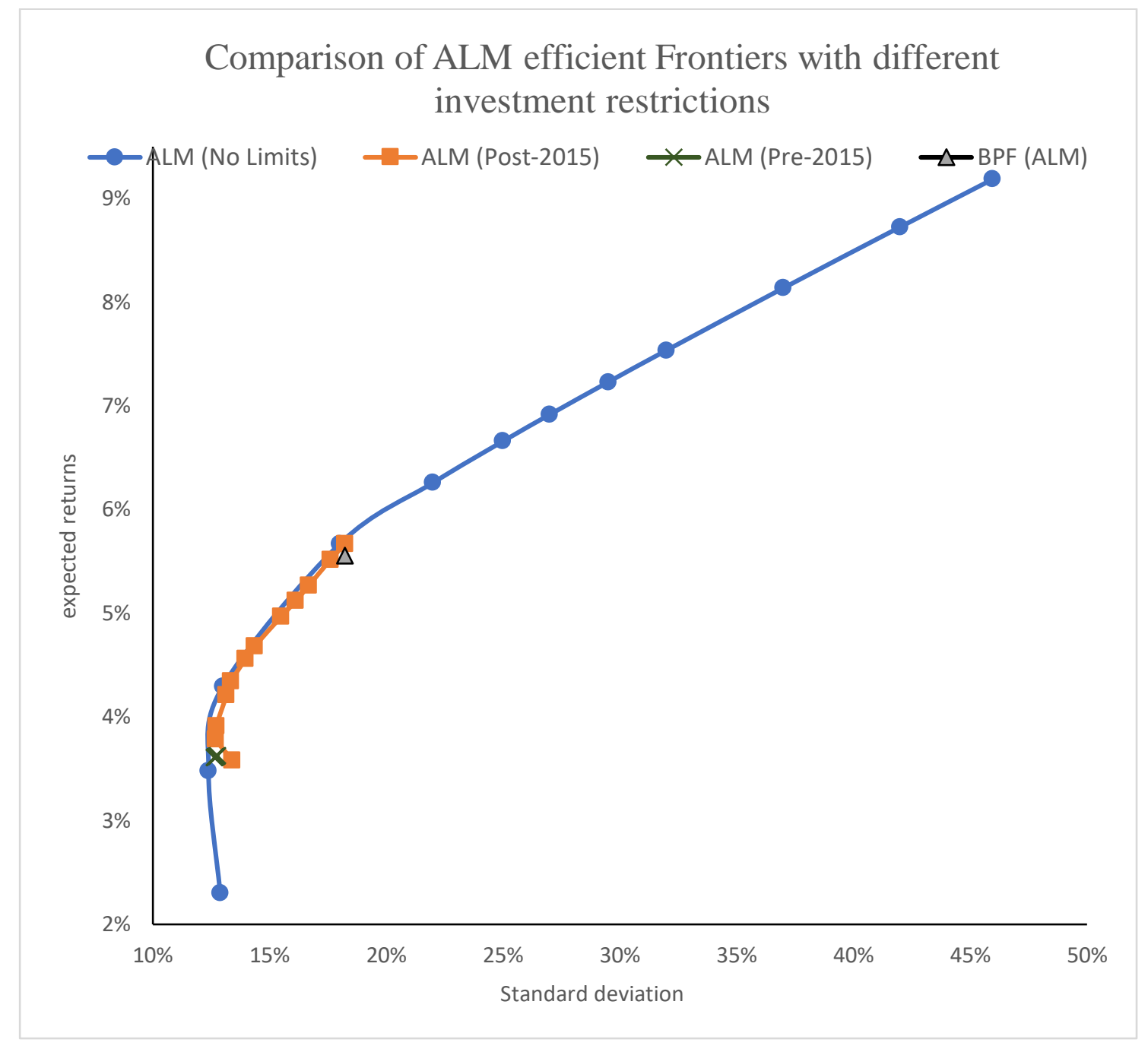

Figure 3: Asset-Liability Efficient Frontiers

\subsubsection{Assets-Only Model with Social Security Fund Limits}

The NSSF accesses foreign investments through international fund managers. The Social Security Fund has performed much better than the BPF (Leckie and Pan, 2007), with an average return of 7.1\% from 2011 to 2016, and 8.37\% since 2000 (Zhang and Harte, 2017). This superior performance may be for two different reasons. First, the NSSF benefits from superior investment expertise, economies of scale, insider trading, the use of external fund managers and access to additional types of asset; and these can also benefit pooled investment by the NSSF of the pillar 1B assets. Second, the Social Security Fund benefits from less restrictive limits on investment in domestic equities and is allowed to invest in foreign equities and bonds (see Table 2). This advantage is not available to those provinces who transfer their funds to the NSSF, as transferred funds remain subject to the pillar 1B investment limits. To quantify the 
size of this second advantage, we compare the assets-only efficient frontiers (plotted in Figure 4) for the Social Security Fund using both its own investment limits and the post-2015 pillar 1B limits ${ }^{15}$. This figure shows that the post-2015 efficient frontier lies to the left of the frontier with Social Security Fund limits, indicating that investment of pillar 1B funds by the NSSF will increase returns for two reasons - more favourable investment limits, and superior investment expertise, economies of scale, and insider trading.

Details of the assets-only efficient portfolio with Social Security Fund limits appear in Table 6, and like the ALM portfolio with no investment limits, there is no allocation to foreign assets, except for portfolios 1 to 3 .

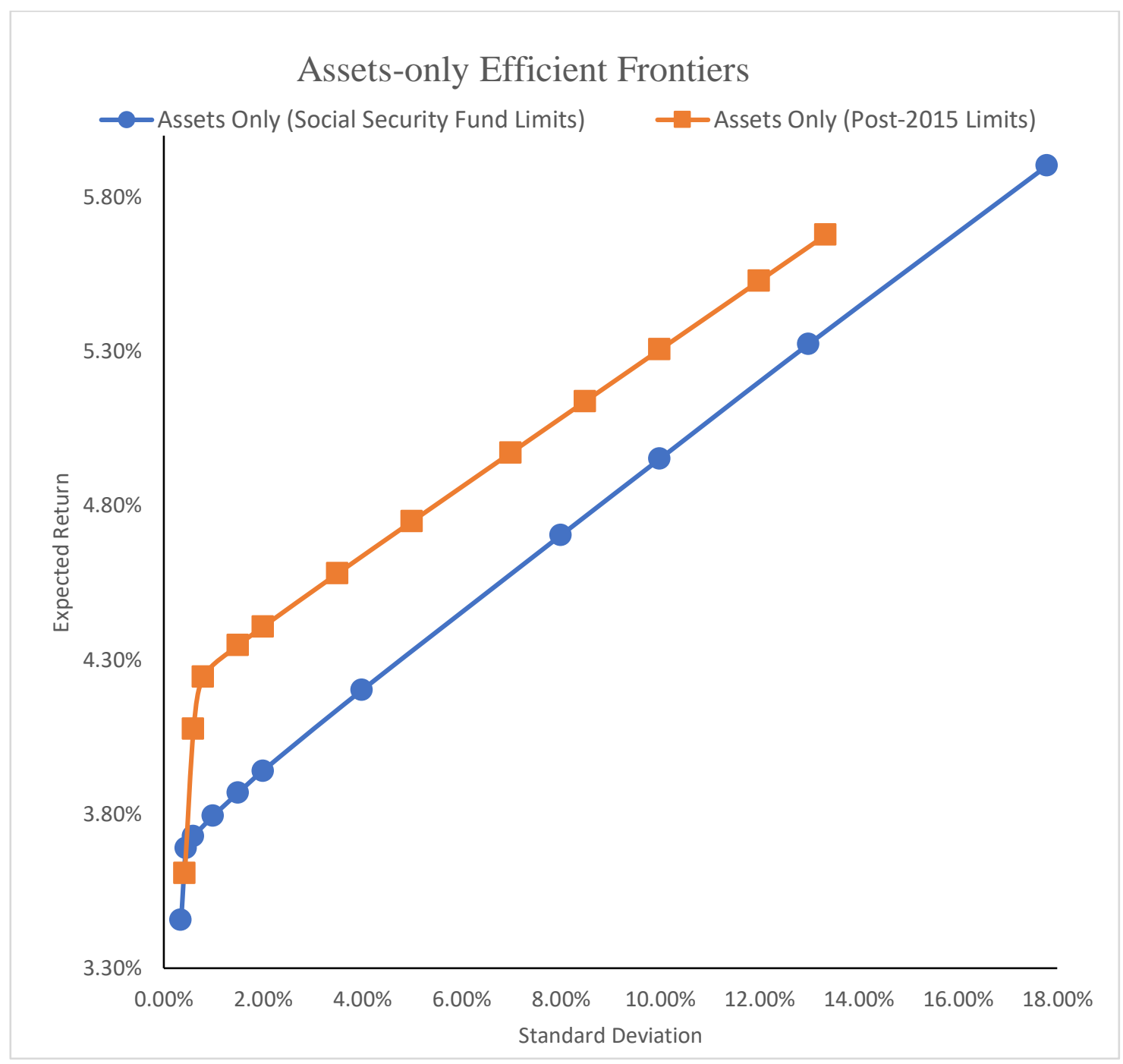

Figure 4: Assets-Only Efficient Frontiers for Social Security Fund and Post-2015 Limits

\footnotetext{
${ }^{15}$ For example, ALM portfolio 11, which plots close to the actual BPF portfolio, has an expected return of $-25.52 \%$, not $5.52 \%$, when the liability returns are included.
} 


\subsection{Retirement Age of 65}

There has been a lot of discussion in the literature about delaying retirement in China (James, 2002; Queisser et al., 2016; İmrohoroğlu and Zhao, 2018), and we examine the effects on the asset allocation of an immediate increase in the retirement age to 65 in 2016, which is the statutory or average retirement age in many developed countries, for all three groups of members. While members will contribute for longer, current assets will be unchanged. Increasing the retirement age affects the liabilities as it decreases the time spent in retirement, which alters the rate of change, volatility and total amount of the six liabilities. As members will contribute for longer, and receive a pension for a shorter period, the annuity factors in equation 1 need to be adjusted. We assume the annuity factors for male employees (139), female officers (170) and female blue-collar workers (195) are reduced by the same proportion as the reduction in their expected longevity at retirement. For example, in 2016, the average life expectancy of male members at the age of 60 is 14.8 years, retirement at 65 , not 60 , implies a reduction in their period drawing a pension of $33.78 \%$. A summary of these changes is provided in Appendix 2. Delaying retirement to 65 increases the liabilities for active members by over $40 \%$, mainly due to the reductions in the annuity factors. The liabilities for pensioners younger than 65 are not changed, as we treat retirement as irreversible.

In Figure 5 we compare the efficient frontiers of the ALM (post-2015 limits) and the current retirement ages, and with a retirement age of 65 . Figure 5 shows that if the retirement age was increased to 65 in 2016, the ALM efficient frontier shifts a long way to the right of its original position. For little higher expected return, portfolios with retirement at 65 have much higher risk. This is because raising the retirement age increases the magnitude of the liabilities by over $40 \%$, and their standard deviation by over $30 \%$. Only portfolios 1-4 provide positive effectiveness, with a highest reduction of liability risk of $0.58 \%$. The ALM efficient portfolios with a 65-year retirement age are in Table 6.

With more pension contributions, and smaller pension payments due to a modest reduction in the size of the annuity factor and no more than a small increase in longevity induced by later retirement, delaying retirement will probably improve the sustainability of the PAYG system (pillar 1A) (Wang and Shan, 2016). This will help to postpone the time when the cash flow of pillar $1 \mathrm{~A}$ becomes negative. 


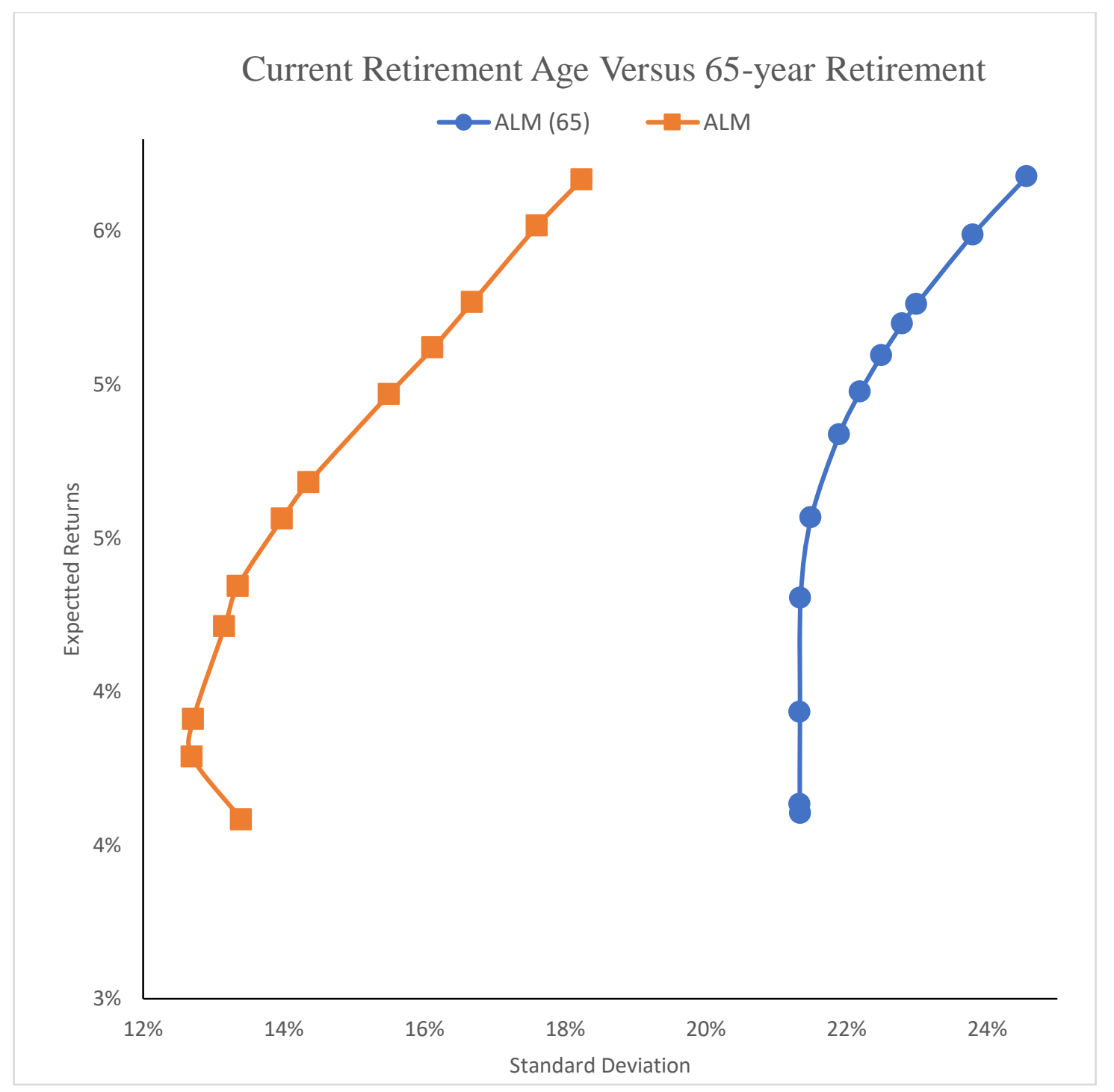

Figure 5: Asset-Liability Efficient Frontiers with the Current Retirement Ages and Retirement at 65

\section{Conclusions}

The Chinese pension system faces some very considerable challenges. The state scheme (pillar 1) dominates the pension system, and we study the individual accounts of pillar 1B of the state scheme, which is a funded cash balance scheme. We find that the total actuarial liabilities of pillar 1B are much larger than the accumulated balances in the individual accounts, and in 2016 it had a funding ratio of only $73.5 \%$. This low funding ratio is forecast to get substantially worse, and improved investment performance is urgently needed. We use portfolio theory, both with and without the liabilities, to study the asset allocation of pillar 1B. To this end we divide the calculation of the actuarial liability into six different types - active members and pensioners in three groups (male employees, female officers in public institutions and female blue-collar workers). 
Using the post-2015 limits on the investment of the pillar 1B funds, we demonstrated that the asset allocation of these funds should use an asset-liability model (ALM), rather than the conventional assets-only portfolio model. We also show that the pre-2015 limits, which only allowed investment in government bonds and bank deposits, result in portfolios with very similar risk and return that lie at the bottom end of the post-2015 efficient frontier with low return and low risk. With the removal of all investment restrictions the efficient frontier meanvariance dominates the frontier when post-2015 limits apply, and this relaxation greatly expands the length of the efficient frontier by allowing investment in portfolios with much greater risk and return than is currently possible. Interestingly, these improvements are not due to allowing investment in foreign equities, but to relaxing the restrictions on domestic value stocks and domestic corporate bonds. Therefore, China should consider relaxing the restriction on investment of pillar 1B funds in domestic assets as this both improves and expands the efficient frontier.

The investment track record of the NSSF in managing the Social Security Fund is superior to that of the provinces This is due to some combination of greater expertise, economies of scale, private information, investment in additional asset classes and the use of external fund managers (Shen et al, 2019). When managing pillar 1B funds the NSSF must observe the pillar 1B investment restrictions, rather than the Social Security Fund restrictions; and we find that this will further increase the investment performance of the NSSF when managing provincial pension funds. Moving funds to the NSSF will also limit the misuse of these funds by the provinces.

A common way of addressing pension underfunding is to increase the retirement age. If the Chinese retirement age was increased to 65 , we find that the liabilities of active members increase by over $40 \%$. When we include these liabilities, compared to the ALM with current retirement ages, while the expected returns of asset-liability portfolios are largely unchanged, their risk increases considerably. As a result, an instantaneous increase in the retirement age to 65 is a challenging pension reform option for China because there is no accompanying increase in assets. However, if the increased retirement date was applied only to those currently of working age, they and the state would contribute for longer. The resulting increase in assets, coupled with the shorter period of retirement and appropriate annuity factors, should improve the scheme's funding ratio. To quantify the effects on the funding ratio over time requires a dynamic analysis of pillar 1B, and the problems of employing the elderly in China need further discussion. 
This paper has several implications for the reform of pillar 1B of the BPF. First, asset allocation using an ALM is preferable to an assets-only approach, if only because it reveals the correct risks and returns of the scheme and prevents fund managers and the government from thinking the current investment regulations are compatible with boosting the previous sluggish performance. Second, relaxing the restrictions on investment in domestic value stocks and corporate bonds would improve investment performance. Third, transferring provincial pension funds to the NSSF for investment should lead to better investment performance, and discourage empty accounts. Fourth, increasing the retirement age is an obvious policy to improve the pillar 1B funding ratio, although this change needs to be carefully designed. Finally, the official notional rate of return on individual accounts (pillar 1B) is uniformly set at $5 \%$ for $2014-2015$ and $8.31 \%$ for 2016 . Investment returns may be sufficient to meet a $5 \%$ notional rate per annum, but a notional rate of over $8 \%$ may be higher than can be achieved. This will lead to an increase in the liabilities, and a worse funding ratio. The choice of a reasonable notional rate, and the relationship between pillar 1B fund investment and notional rate need further investigation. We leave the analysis of this issue and raising the retirement age to future research. 


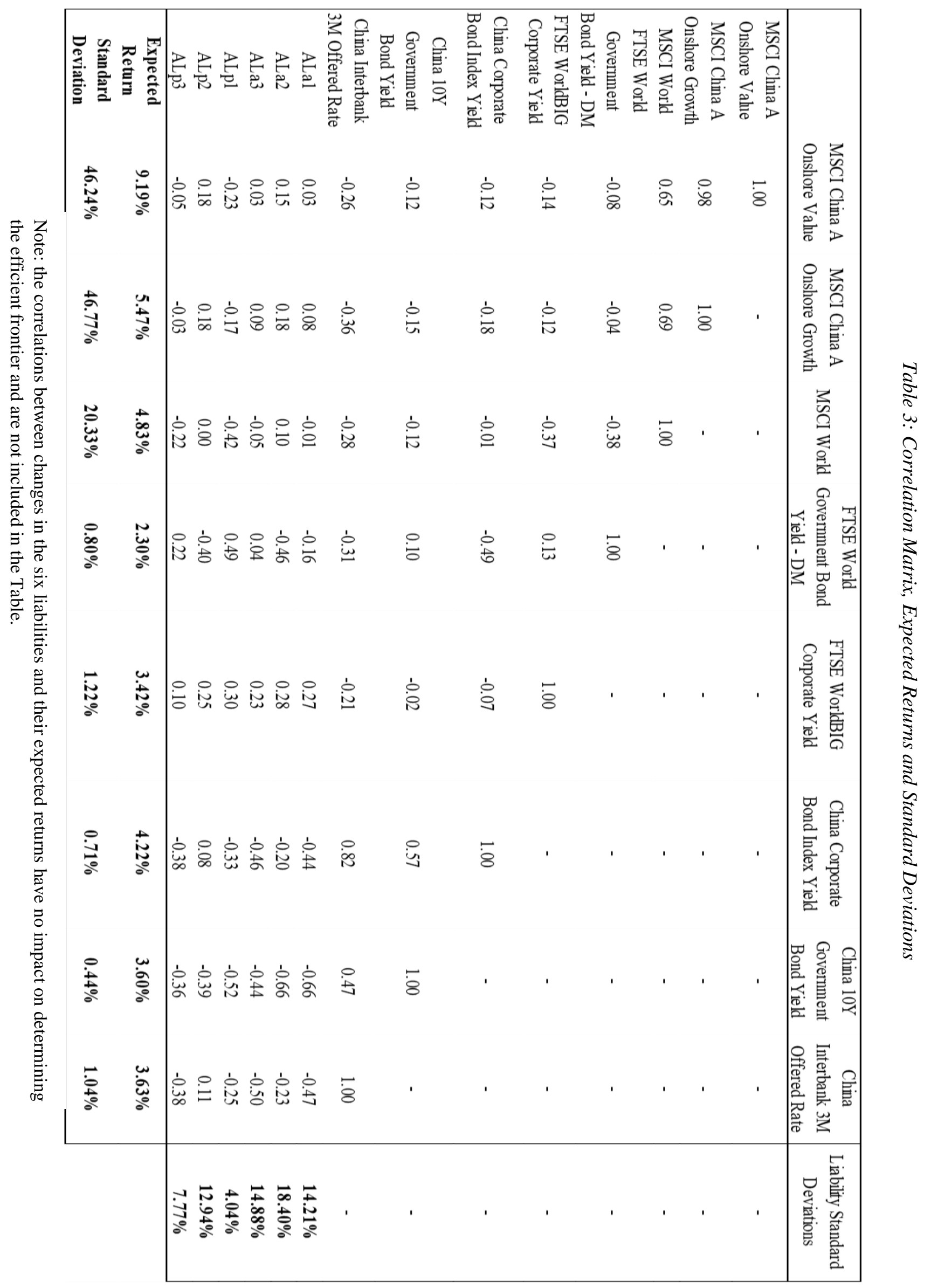




\begin{tabular}{|c|c|}
\hline 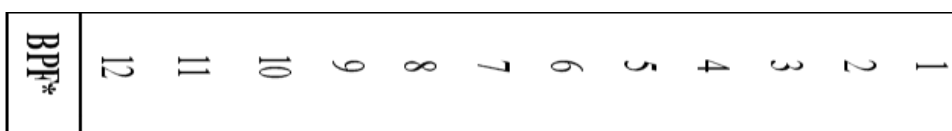 & \\
\hline 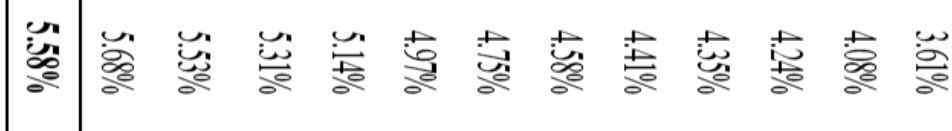 & 倌辠 \\
\hline 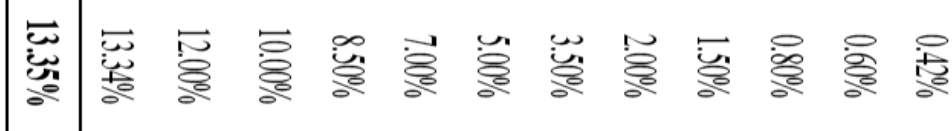 & 容鲸 \\
\hline 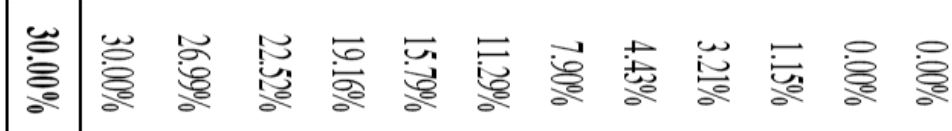 & 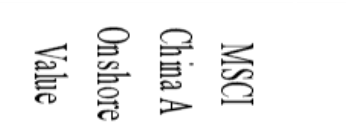 \\
\hline 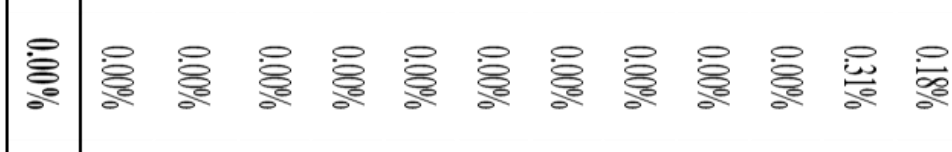 & 量喜最虽 \\
\hline 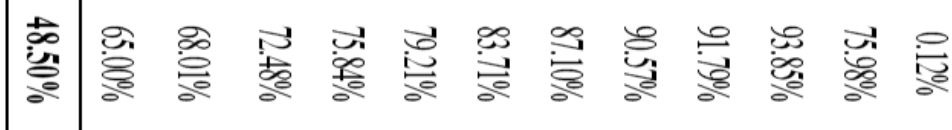 & 署量量 \\
\hline 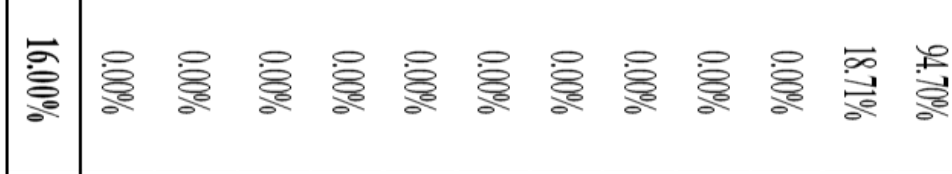 & 置墨毫 \\
\hline 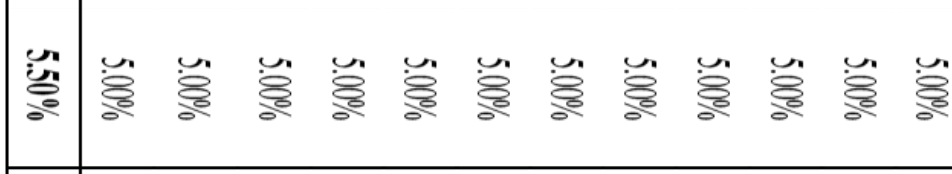 & 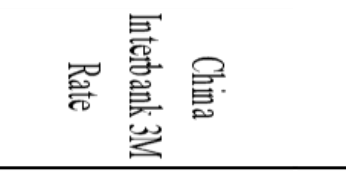 \\
\hline 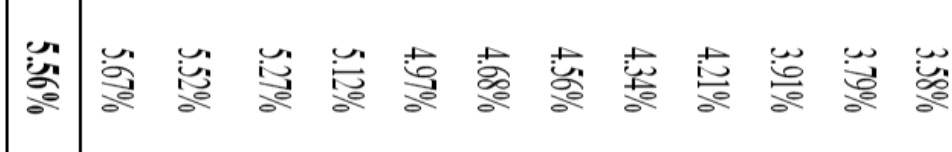 & 䍚墨基 \\
\hline 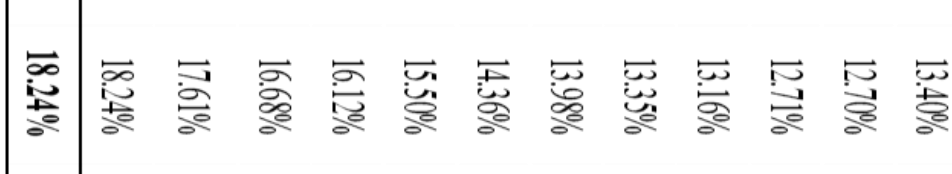 & 墨兽 \\
\hline 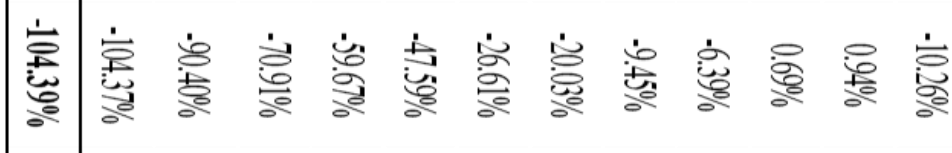 & 量䍗 \\
\hline 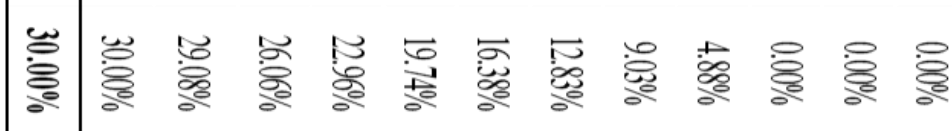 & 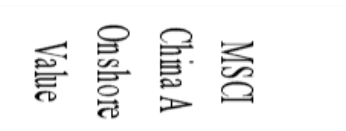 \\
\hline 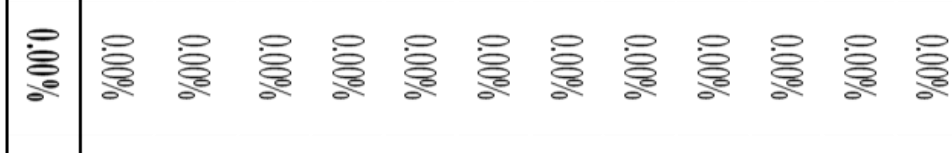 & 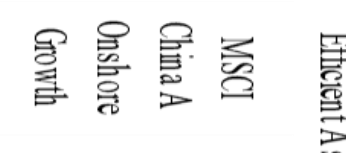 \\
\hline 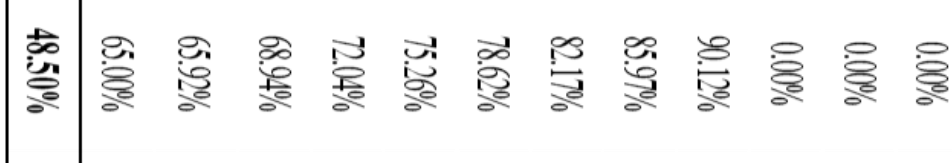 & 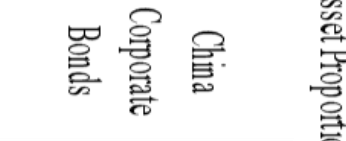 \\
\hline 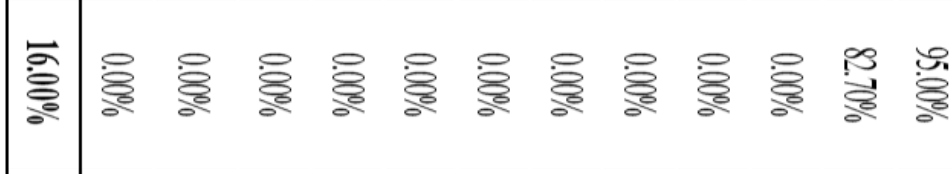 & 罟墨憘 \\
\hline 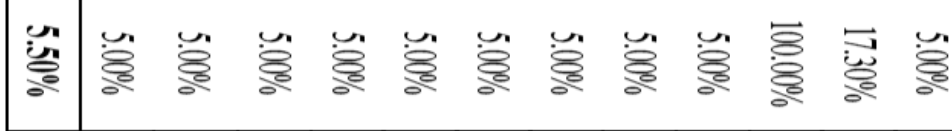 & 詈量最 \\
\hline
\end{tabular}




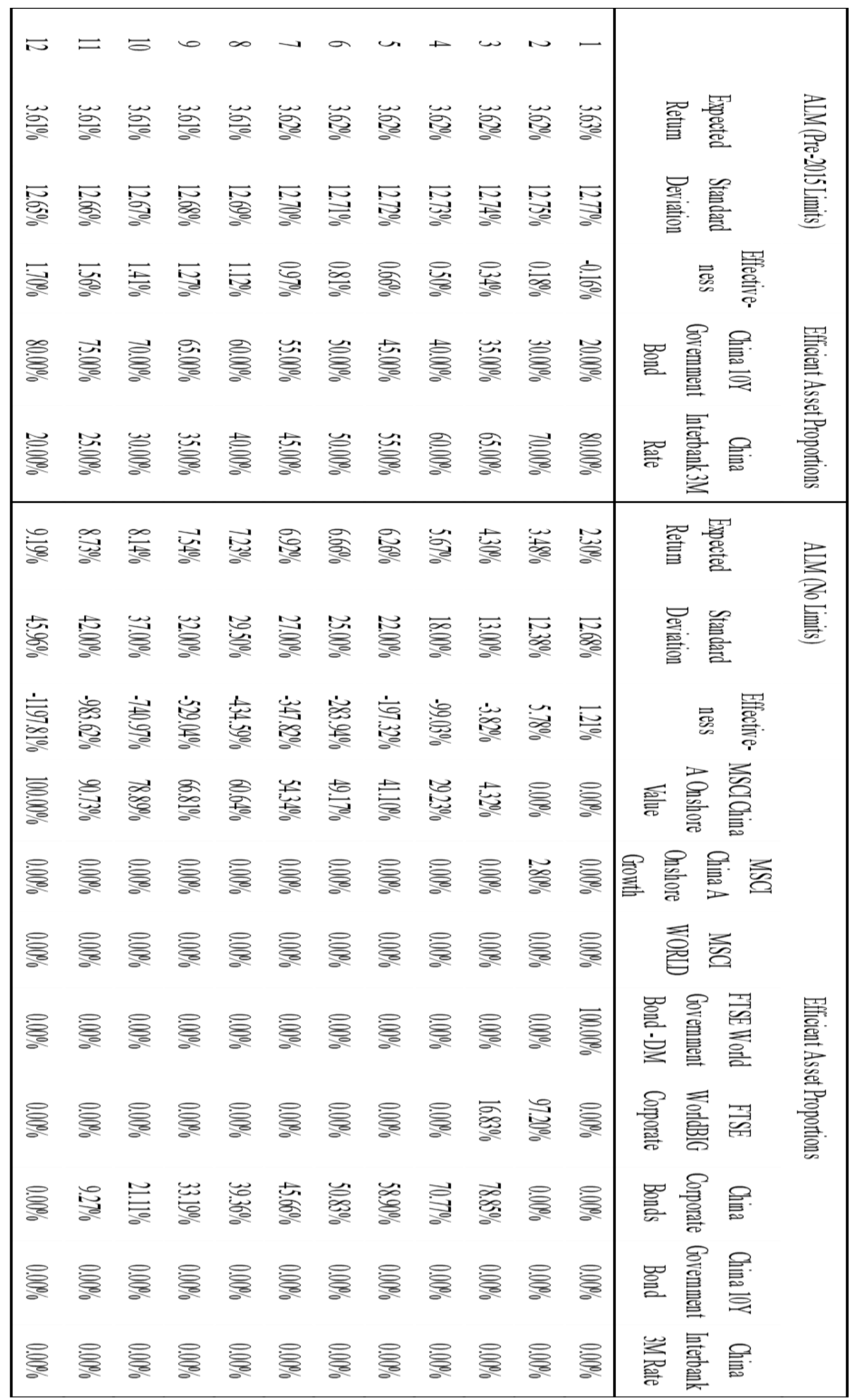

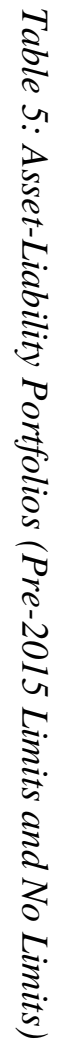




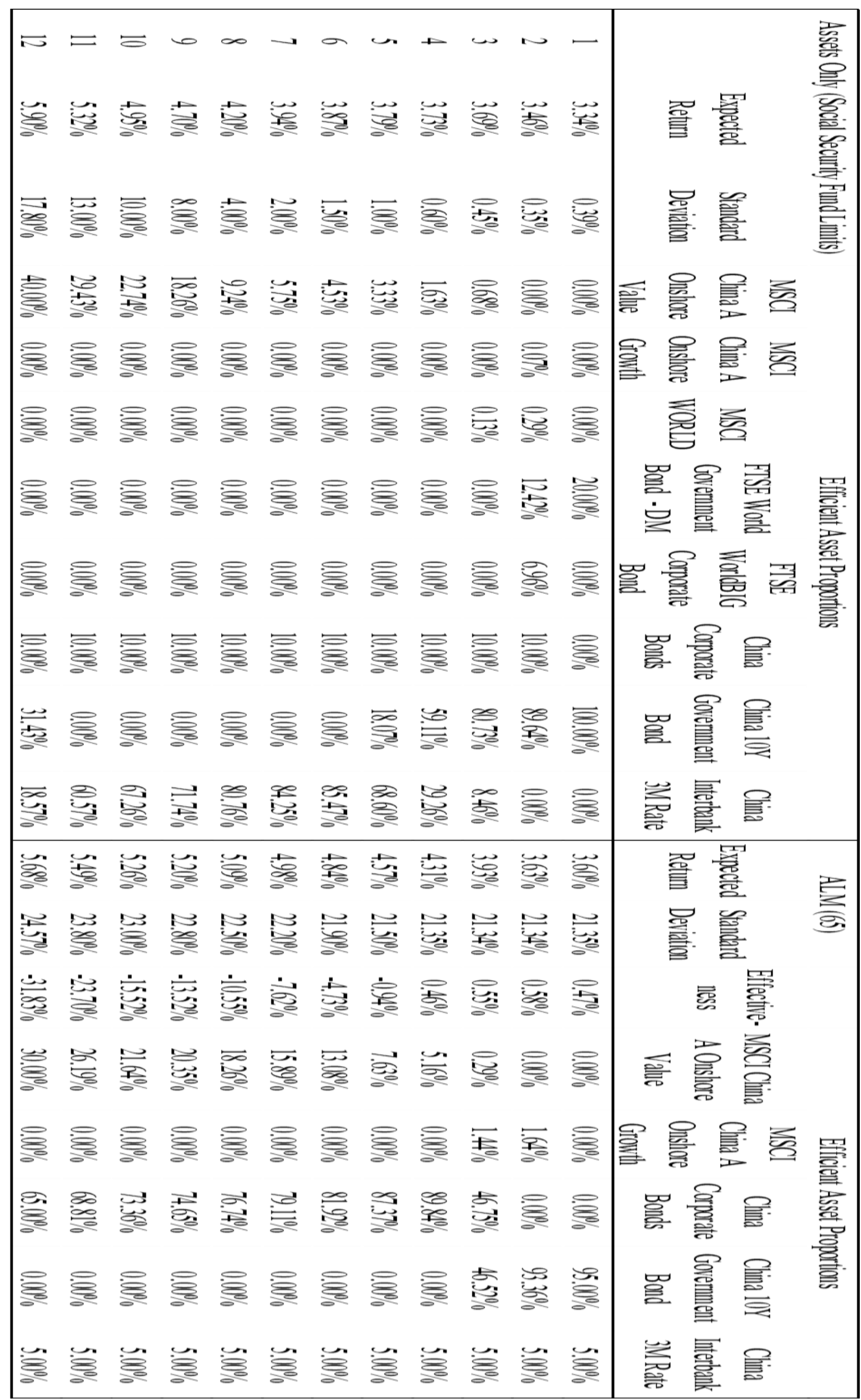

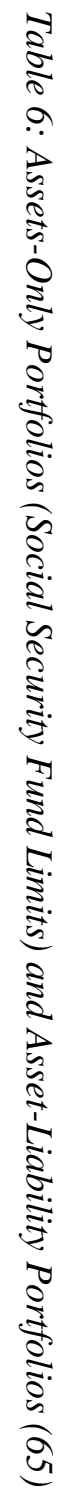


Appendix 1: Summary Statistics of Demographic Data

\begin{tabular}{|c|c|c|c|c|c|c|c|}
\hline \multicolumn{8}{|c|}{ Table 1: Summary Statistics of Actuarial Vahues for Active Members (2001-2016) } \\
\hline \multirow[b]{2}{*}{ Vahes } & \multirow[b]{2}{*}{ Mean } & \multirow[b]{2}{*}{ S.D. } & \multicolumn{5}{|c|}{ Quantiles } \\
\hline & & & $0 \%$ & $25 \%$ & $50 \%$ & $75 \%$ & $100 \%$ \\
\hline Number of Males (in Million) & 114.70 & 38.78 & 67.08 & 75.83 & 107.47 & 157.15 & 176.98 \\
\hline Number of Female Officers (in Million) & 19.40 & 8.44 & 11.29 & 12.47 & 15.09 & 25.74 & 37.27 \\
\hline Number of Female Workers (in Million) & 47.33 & 12.93 & 27.18 & 31.36 & 51.05 & 58.88 & 64.01 \\
\hline Average Current Age of Males & 38.84 & 0.78 & 37.32 & 38.36 & 39.03 & 39.47 & 40.01 \\
\hline Average Current Age of Female Officers & 36.18 & 0.34 & 35.59 & 35.88 & 36.17 & 36.38 & 36.92 \\
\hline Average Current Age of Female Workers & 37.61 & 1.65 & 35.03 & 36.33 & 37.55 & 38.94 & 40.41 \\
\hline Average Service Length of Males & 21.18 & 0.77 & 20.00 & 20.51 & 21.12 & 21.77 & 22.65 \\
\hline Average Service Length of Female Officers & 18.59 & 0.52 & 17.72 & 18.19 & 18.67 & 18.92 & 19.68 \\
\hline Average Service Length of Female Workers & 20.02 & 1.31 & 17.81 & 18.88 & 20.06 & 21.04 & 22.01 \\
\hline Life Expectancy at Retirement(Males) & 13.23 & 1.21 & 10.87 & 12.20 & 13.45 & 14.32 & 14.80 \\
\hline Life Expectancy at Retirement (Female Officers) & 21.29 & 1.18 & 19.08 & 20.22 & 21.53 & 22.34 & 22.83 \\
\hline Life Expectancy at Retirement (Female Workers) & 26.29 & 1.18 & 24.08 & 25.22 & 26.53 & 27.34 & 27.83 \\
\hline Average Annual Salary of Males ( $¥)$ & $35,958.31$ & $19,804.00$ & $11,557.17$ & $16,988.64$ & $32,582.29$ & $54,640.40$ & $71,889.29$ \\
\hline Average Annual Salary of Females ( $¥)$ & $30,021.59$ & $16,534.36$ & $9,649.08$ & $14,183.81$ & $27,202.95$ & $45,619.27$ & $60,020.37$ \\
\hline
\end{tabular}

\begin{tabular}{|c|c|c|c|c|c|c|c|}
\hline \multicolumn{8}{|c|}{ Table 2: Summary Statistics of Actuarial Vahues for Pensioners (2001-2016) } \\
\hline \multirow[b]{2}{*}{ Vahes } & \multirow[b]{2}{*}{ Mean } & \multirow[b]{2}{*}{ S.D. } & \multicolumn{5}{|c|}{ Quantiles } \\
\hline & & & $0 \%$ & $25 \%$ & $50 \%$ & $75 \%$ & $100 \%$ \\
\hline Number of Males (in Million) & 38.13 & 13.91 & 20.99 & 25.40 & 34.78 & 52.27 & 64.26 \\
\hline Number of Female Officers (in Million) & 6.47 & 3.07 & 3.76 & 4.01 & 5.03 & 8.56 & 13.53 \\
\hline Number of Female Workers (in Million) & 15.70 & 4.59 & 8.51 & 10.50 & 16.52 & 19.58 & 23.24 \\
\hline Average Current Age of Males & 69.03 & 0.20 & 68.67 & 68.85 & 69.08 & 69.23 & 69.30 \\
\hline Average Current Age of Female Officers & 66.16 & 0.30 & 65.76 & 65.88 & 66.09 & 66.50 & 66.62 \\
\hline Average Current Age of Female Workers & 62.46 & 0.15 & 62.21 & 62.30 & 62.50 & 62.56 & 62.75 \\
\hline Average Current Life Expetancy of Males & 4.20 & 1.29 & 2.01 & 3.07 & 4.18 & 5.48 & 6.04 \\
\hline Average Current Life Expetancy of Female Officers & 10.14 & 1.43 & 7.47 & 8.72 & 10.63 & 11.38 & 11.70 \\
\hline Average Current Life Expetancy of Female Workers & 13.83 & 1.18 & 11.32 & 12.93 & 14.12 & 14.78 & 15.30 \\
\hline Average Annual Pension Benefits of Males ( $¥)$ & $17,088.60$ & $8,318.33$ & $7,324.67$ & $9,109.29$ & $15,587.30$ & $24,378.91$ & $33,543.66$ \\
\hline Average Annual Pension Benefits of Females (\#) & $14,267.27$ & $6,944.97$ & $6,115.37$ & $7,005.35$ & $13,013.83$ & $20,353.95$ & $28,005.60$ \\
\hline
\end{tabular}

Sources: MOHRSS (2002-2017a), National Bureau of Statistics of China (2018), World Bank (2018) and authors' own calculations. 
Appendix 2: Changes in Liabilities for Active Members with a Single Retirement Age

\begin{tabular}{|c|c|c|c|c|c|c|c|c|c|c|}
\hline & \multicolumn{5}{|c|}{ Current Retirement Age } & \multicolumn{5}{|c|}{ 65-year Retirement Age } \\
\hline & $\begin{array}{l}\text { Average } \\
\text { Rate of } \\
\text { Change }\end{array}$ & $\begin{array}{l}\text { Average } \\
\text { Volatility }\end{array}$ & $\begin{array}{l}\text { Average } \\
\text { Life } \\
\text { Expectancy } \\
\text { of Active } \\
\text { Members }\end{array}$ & $\begin{array}{l}\text { Annuity } \\
\text { Factor }\end{array}$ & $\begin{array}{l}\text { Forecast } \\
\text { Amount } \\
\text { (Billion, } \\
¥, 2016 \text { ) }\end{array}$ & $\begin{array}{l}\text { Average } \\
\text { Rate of } \\
\text { Change }\end{array}$ & $\begin{array}{l}\text { Average } \\
\text { Volatility }\end{array}$ & $\begin{array}{l}\text { Average } \\
\text { Life } \\
\text { Expectancy } \\
\text { of Active } \\
\text { Members }\end{array}$ & $\begin{array}{c}\text { New } \\
\text { Annuity } \\
\text { Factor } \\
\text { in } 2016\end{array}$ & $\begin{array}{l}\text { Forecast } \\
\text { Amount } \\
\text { (Billion, } \\
¥, 2016 \text { ) }\end{array}$ \\
\hline ALa1 & $25.39 \%$ & $14.21 \%$ & 13.23 & 139 & 1969 & $26.40 \%$ & $15.56 \%$ & 12.92 & 92.02 & 2290 \\
\hline ALa2 & $24.94 \%$ & $18.40 \%$ & 21.29 & 170 & 472 & $27.56 \%$ & $22.95 \%$ & 20.67 & 95.55 & 699 \\
\hline ALa3 & $17.11 \%$ & $14.88 \%$ & 26.29 & 195 & 743 & $22.13 \%$ & $26.17 \%$ & 25.35 & 89.91 & 1578 \\
\hline
\end{tabular}

Sources: Authors' calculations based on actuarial liability models and demographic assumptions. 


\section{References}

Actuarial Education Company, 2002. Acted Study Materials: 2002 Examinations, Subject 304, Course

Notes. Actuarial Education Company, Oxford.

Alda, M., 2017. The relationship between pension funds and the stock market: Does the aging population of Europe affect it?. International Review of Financial Analysis, 49, pp.83-97.

Barr, N. and Diamond, P., 2010. Pension reform in China: issues, options and recommendations. China Economic Research and Advisory Programme.

Bassett, W.F., Fleming, M.J. and Rodrigues, A.P., 1998. How workers use 401 (k) plans: The participation, contribution, and withdrawal decisions. National Tax Journal, pp.263-289.

Bateman, H. and Liu, K., 2017. Pension reform: Australia and China compared. Economic and Political Studies, 5(4), pp.456-474.

Bikker, J.A., 2017. Is There an Optimal Pension Fund Size? A Scale-Economy Analysis of Administrative Costs. Journal of Risk and Insurance, 84(2), pp.739-769.

Board, J. and Sutcliffe, C., 2007. Joined-Up Pensions Policy in the UK: An Asset-Liability Model for Simultaneously Determining the Asset Allocation and Contribution Rate. 1Handbook of Asset and Liability Management, edited by Stavros A. Zenios and William T. Ziemba, North Holland Handbooks in Finance, Elsevier Science B.V., Volume 2, 2007, pp. 1029-1067

Bohl, M.T., Brzeszczyński, J. and Wilfling, B., 2009. Institutional investors and stock returns volatility: Empirical evidence from a natural experiment. Journal of Financial Stability, 5(2), pp.170-182.

Cahill, K. and Soto, M., 2003. How Do Cash Balance Plans Affect the Pension Landscape?. The Centre for Retirement Research, Boston College.

Cai, Y. and Cheng, Y., 2014. Pension reform in China: challenges and opportunities. Journal of Economic Surveys, 28(4), pp.636-651.

Chemla, G., 2004. Pension fund investment in private equity and venture capital in the US and Canada. The Journal of Private Equity, pp.64-71.

Chinese Insurance Regulation Commission (CIRC), 2015. Annual Report of the Chinese Insurance Market 2015. The Chinese Insurance Regulation Commission, Beijing. Viewed 12 December 2018.

Craft, T., 2001. The role of private and public real estate in pension plan portfolio allocation choices. Journal of Real Estate Portfolio Management, 7(1), pp.17-23.

Craft, T.M., 2005. Impact of pension plan liabilities on real estate investment. The Journal of Portfolio Management, 31(5), pp.23-31.

Dong, K. and Wang, G., 2016. China's pension system: achievements, challenges and future developments. Economic and Political Studies, 4(4), pp.414-433.

Dorfman, M.C., Holzmann, R., O'Keefe, P., Wang, D., Sin, Y. and Hinz, R., 2013. China's pension system: A vision. The World Bank.

Dyck, I.J. and Pomorski, L., 2011. Is bigger better? Size and performance in pension plan management, Working paper, Rotman School of Management.

Ederington, L.H., 1979. The hedging performance of the new futures markets. The Journal of Finance, 34(1), pp.157-170.

Ezra, D.D., 1991. Asset allocation by surplus optimization. Financial Analysts Journal, 47(1), pp.5157. 
Fan, G., 2010. A method of forecasting coefficients in the logistic model and its applications [一种估 计 Logistic 模型参数的方法及应用实例]. Mathematics in Economics [经济数学], 27(1), pp.105-110.

Fang, H. and Feng, J., 2018. The Chinese Pension System (No. w25088). National Bureau of Economic Research.

Faugere, C. and Shawky, H.A., 2003. Volatility and Institutional Investor Holdings in a Declining Market: A Study of Nasdaq during the Year 2000. Journal of Applied Finance, 13(2), p.32.

Feldstein, M., 1999. Social security pension reform in China. China Economic Review, 10(2), pp.99107.

Feng, W., Gu, B. and Cai, Y., 2016. The end of China's one-child policy. Studies in Family Planning, 47(1), pp.83-86.

Frazier, M.W., 2010. Socialist insecurity: Pensions and the politics of uneven development in China (p. 2). Ithaca, NY: Cornell University Press.

FTSE Russell, 2018. FTSE World Government Bond Index - Developed Markets (WGBI-DM), FTSE Russell Factsheet, London.

FTSE Russell, 2019. FTSE World Broad Investment-Grade Bond Index (WorldBIG), FTSE Russell Factsheet, London.

Hoevenaars, R.P., Molenaar, R.D., Schotman, P.C. and Steenkamp, T.B., 2008. Strategic asset allocation with liabilities: Beyond stocks and bonds. Journal of Economic Dynamics and Control, 32(9), pp.2939-2970.

Hu, J., 2017. Strategies, Risk Control and Investment Policy of Social Insurance Funds in China. EUChina Social Protection Reform Project: Component 2, pp.6-45.

Hu, Y.W., Impavido, G. and Li, X., 2009. Governance and fund management in the Chinese pension system (No. 9-246). International Monetary Fund.

Hu, Y.W., Stewart, F. and Yermo, J., 2007. Pension fund investment and regulation: An international perspective and implications for China's pension system. Private Pension System: Developments and Issues, OECD.

İmrohoroğlu, A. and Zhao, K., 2018. Intergenerational transfers and China's social security reform. The Journal of the Economics of Ageing, 11(May 2018), pp.62-70.

Inkmann, J., Blake, D. and Shi, Z., 2017. Managing financially distressed pension plans in the interest of beneficiaries. Journal of Risk and Insurance, 84(2), pp.539-565.

James, E., 2002. How can China solve its old-age security problem? The interaction between pension, state enterprise and financial market reform, Journal of Pension Economics \& Finance, 1(1), pp.53-75.

Jia, H., 2017. An evaluation of pension differentials between Chinese private and public sectors from perspective of protection and incentives over the lifecycle, China Economic Review, 44, pp.16-29.

Jin, Y., 2017, 'A Study on the Asset and Liability Management of Basic Pension Fund' [基本养老保 险基金资产负债管理研究], PhD thesis, School of Management, Zhejiang University, viewed 29 October 2018, CNKI, F842.67.

Kuhn, P. and Shen, K., 2012. Gender discrimination in job ads: Evidence from china. The Quarterly Journal of Economics, 128(1), pp.287-336.

Leckie, S. and Pan, N., 2007. A review of the national social security fund in China. Pensions: An International Journal, 12(2), pp.88-97. 
Leung, J.C., 2003. Social security reforms in China: Issues and prospects. International Journal of Social Welfare, 12(2), pp.73-85.

Li, C. and Lin, S., 2019. China's explicit social security debt: How large?. China Economic Review, 53, pp.128-139.

Li, H. and Mérette, M., 2005. Population ageing and pension system reform in China: a computable overlapping-generations general equilibrium model analysis. Journal of Chinese Economic and Business Studies, 3(3), pp.263-277.

Lin, Z., 2004. Regional disparities in social security in China and transfer payments. Chinese Economy, 37(5), pp.59-73.

Liu, T. and Sun, L., 2016. Pension reform in China. Journal of aging \& social policy, 28(1), pp.15-28.

Liu, X., Zhang, Y., Fang, L., Li, Y. and Pan, W., 2015. Reforming China's pension scheme for urban workers: Liquidity gap and policies' effects forecasting. Sustainability, 7(8), pp.10876-10894.

Mitchell, O.S. and Andrews, E.S., 1981. Scale economies in private multi-employer pension systems. ILR Review, 34(4), pp.522-530.

MOHRSS, 1997. Individual account management regulations of basic pension fund for urban and rural residents [城乡居民基本养老保险个人账户管理规范], MOHRSS, Beijing, viewed 27 December 2017.

MOHRSS, 2002 to 2017a. China Labour Statistical Yearbook 2002-2017 [ 中国劳动统计年鉴2002 至2017]. China Statistics Press, viewed 20 January 2019.

MOHRSS, 2017b. Measures for unifying and standardising the notional rate on individual accounts of urban employees' basic pension fund [统一和规范职工养老保险个人账户记账利率办法], MOHRSS, Beijing, viewed 12 October 2018.

MOHRSS, 2017c. Notice on the announcement of notional rate of individual accounts and other parameters of the basic pension fund for urban employees in 2016 [公布2016 年职工基本美老保险 个人账户记账利率等参数的通知], MOHRSS, Beijing, viewed 12 October 2018.

MSCI, 2019a. MSCI CHINA A ONSHORE INDEX, MSCI, New York, viewed 02 January 2019.

MSCI, 2019b. MSCI CHINA A ONSHORE GROWTH INDEX, MSCI, New York, viewed 02 January 2019.

MSCI, 2019c. MSCI CHINA A ONSHORE VALUE INDEX, MSCI, New York, viewed 02 January 2019.

MSCI, 2019d. MSCI WORLD INDEX, MSCI, New York, viewed 01 January 2019.

National Bureau of Statistics of China, 2018. National Statistics [国家数据], National Bureau of Statistics of China, viewed 22 August 2018.

Ning, M., Gong, J., Zheng, X. and Zhuang, J., 2016. Does new rural pension scheme decrease elderly labour supply? Evidence from CHARLS, China Economic Review, 41, pp.315-330.

NSSF, 2018. Annual report on entrusted operation of the basic pension fund in 2017 [ 基本养老保险 基金受托运营 2017 年度报告]. National Council for Social Security Fund, Beijing, viewed 15 December 2018.

OECD, 2017. China: Pension system in 2016, OECD, Paris, France, viewed 12 January 2018. 
Oksanen, H. 2012. China: Pension Reform for an Aging Economy. In Nonfinancial Defined Contribution Pension Schemes in a Changing Pension World, Volume I, Progress, Lessons, and Implementation, edited by R. Holzmann, E. Palmer and D. Robalino, World Bank, 213-255.

Peng, X., 2008. Demographic shift, population ageing and economic growth in China: A computable general equilibrium analysis. Pacific Economic Review, 13(5), pp.680-697.

Pfau, W.D., 2011. Emerging market pension funds and international diversification. The Journal of Developing Areas, 45(Fall), pp.1-17.

Queisser, M., Reilly, A. and Hu, Y., 2016. China's pension system and reform: an OECD perspective. Economic and Political Studies, 4(4), pp.345-367.

Rudolf, M. and Ziemba, W.T., 2004. Intertemporal surplus management. Journal of Economic Dynamics and Control, 28(5), pp.975-990.

Sharpe, W.F. and Tint, L.G., 1990. Liabilities-a new approach. Journal of Portfolio Management, 16(2), pp.5-10.

Shen, Y., Zhu, K., Wu, F. and Chen, P., 2019. The Stock Investment Performance of Pension Funds in China. Emerging Markets Finance and Trade, pp.1-17.

Sin, Y., 2005. Pension liabilities and reform options for old age insurance. World Bank working paper, 1 . Song, S., 2009. Pension systems and reforms in China and Russia. Chinese Economy, 42(3), pp.9-23.

State Council, 2015. Investment regulations of the basic pension fund [ 基本美老保险基金投资管理 办法], The State Council, Beijing, viewed 13 December 2017.

Sutcliffe, C., 2005. The cult of the equity for pension funds: should it get the boot?. Journal of Pension Economics \& Finance, 4(1), pp.57-85.

Sutcliffe, C., 2016. Investment by Pension Funds. Finance and Occupational Pensions, Palgrave Macmillan UK, pp. 121-190.

Wang, M. and Cai, F., 2008. Gender earnings differential in urban China. Review of Development Economics, 12(2), pp.442-454.

Wang, L., Béland, D. and Zhang, S., 2014a. Pension financing in China: Is there a looming crisis?. China Economic Review, 30, pp.143-154.

Wang, L., Béland, D. and Zhang, S., 2014b. Pension fairness in China. China Economic Review, 28, pp.25-36.

Wang, X. and Shan, G., 2016. Raising the retirement age: the impact on the individual and actuarial balance for Chinese urban workers' basic pensions. Economic and Political Studies, 4(4), pp.397-413.

Wang, Y., Xu, D., Wang, Z. and Zhai, F., 2004. Options and impact of China's pension reform: a computable general equilibrium analysis. Journal of Comparative Economics, 32(1), pp.105-127.

Wei, Z. and Qiu, L., 2014. Application of Linear Regression Analysis in Wages Prediction [线性回归 分析法在工资预测中的应用], Journal of Sichuan University of Science \& Engineering [ 四川理工学 院学报], 27(2), pp.56-58.

World Bank, 2018. DataBank. The World Bank, viewed 23 August 2018, <https://databank.worldbank.org/data/home.aspx>

Xu, J., del Carmen Boado-Penas, M., Turner, J.A. and Center, P.P., 2017. A Financial Assessment of the Chinese Pay-As-You-Go Pension System. Working paper. 
Yang, Y. and Zhou, W., 2017. Regional Disparities in China's Basic Pension Insurance and Labor Migration. The Chinese Economy, 50(5), pp.323-338.

Zhang, H. and Harte, J., 2017. China Pensions Outlook. KPMG China, Hong Kong, viewed 13 June 2018.

Zuo, X., 2014. Reforming pensions to ensure equitable and adequate retirement incomes in China. Equitable and sustainable pensions: Challenges and experience, pp.293-312. 